
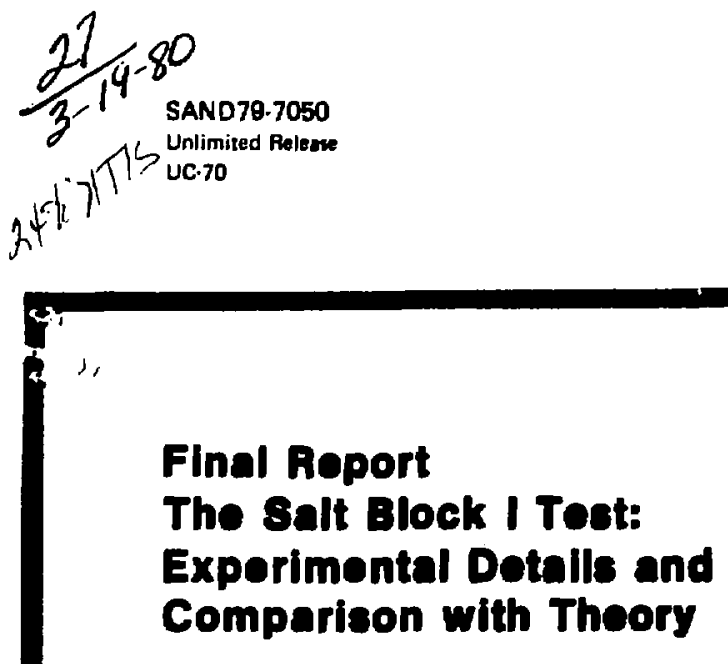

\title{
MASTER
}

T. A. Duffey, Los Alumos Technicat Aneciens, Ine.

Sandia Laboratories 
Los Alamos Technicad Aseoclates, Inc.

LATA 102

FINAL REPORT

The Salt Block I Test: Expertmental Details and Comparison with Theory

Prepared for

A. R. Sattler, Division 4512

Sandia Laboratories, Albuquerque, New Hexico Compiled by

T. A. Duffey, Los Almos Technical Aseociates, Inc.

December 1979 


\section{TABLS OF CONTENTS}

Tople

Pare

I. List of symbols iii

II. List of Firures iv

III. List of Tables vi

Abstract

IV. Introduction 1

V. Prelfainary sall scale Experibents

A. Bcaled Balt Block Heator Test 3

B. 8alt Thermal Conductivity Measurements 3

vI. Salt Block Test I - Ixpertwental Details and Results 8

A. Instrumentation Utllead 8

B. Power Increaces 14

C. Raw Data of 8alt Block Teat I 16

D. Observations on Instrumentation Perfornance and Axisynestry of Thernal Fiald 16

E. Corrosion Coupons 21

F. Water Losece from 8alt Due to Heating 23

VII. Theoretical Inite Element Modelins 25

A. Field Equations and Treatent of Boundary Values 25

B. Convective Hat Transfer Coefficient 27

C. Radiative Heat Tranefer Coefricient 28

D. Discretieation and Numerical solution of the Problem 28

VIII. Experbental-Theoretical Correlations 30

A. Finite Element Modal selocted 30

B. Material Property Valies Ueed as Code Input 31

C. Steady state Comparicons 36

D. Transient Coupariecas 55

E. Discusaion of Discrepancies 55

IX. Sumary of Results and Conchusions 60

$\therefore$ X. References 63

Appanelix:I. Water Loss Data from Salt Diock I (Part 1) 65

Appapioix II. Water Lose Data from salt Block I (Part 2) 


\section{IIST OF sndpoLs}

$\rightarrow$

-

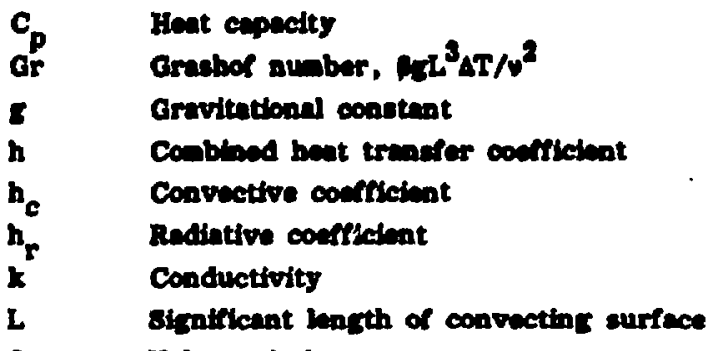

Q Volumetric heat cource

$q_{c} \quad$ Heat hux due to coavection

$q_{n}$ Appliad beat thux vactor composente nornal to boundary

$q_{r}$ Heat mux due to radition

R Outside redius of alt block

r Radial coordinute of cylindor

$T$ ab Ablent air tempernture

$T . \quad$ surfuce temperaturs

t The

2. Hof of salt block

2 Axinl coordinate of cylindor

p Coeficient of therred expension

$r$ Boundary of 8

$\Delta T \quad T_{2}-T_{\text {mab }}$

c Iniesivity of radinting surfece

Niecosity

$\checkmark \quad$ Ineantic ricosity, $\mu / \rho$

p Deasity

- Stephan-Bolmann Coastent

D - Material rezion 


\section{LeT of Founs}

Frure

Numbar Tople

1 Vorticel section of senied Heater Ixpertent.

2 Vertical section of Large Block Beater Expertant Nuber 1.

3 Thernal Conductivity of Rockent fron Mineliselppi Chenical Co. of 8. E. Mew Mexioo, Potach Mithe.

4 Machining of salt Block I into a Cyladrical Epecinen

5 Cuttins of Core specinen (and Henter Hols) from Balt Block I.

6. Locutions of Thermocouples in Relt Dlock 1 .

6b. Instrument Oriantation of Heater Ixperiment

7 Heator Cen and Inent sbowins Therwocouplo Iocetions.

8 Initial Trunsforer Cincuit for Powering Reaistve Heater.

9 Revised Power Circuit for Increased Output Power.

10 Sult Bbek I Dinensions Includine Therecouple Hole Epecticications.

11 Finite Ekwant Numerical Modal of selt Block I.

steady Itate Teoperature Profle Comparieon: $Q=1000 \mathrm{~W}$.

13 Steady state Temperature Prople Comparison: $Q=525 \mathrm{~W}$.

14 Bteady Btate Teoperature Protie Comparicon: $Q=225 \mathrm{~W}$.

15 Stendy State Teoperature Profie Comparieon: $Q=525 \mathrm{~W}$.

16 Steady State Teaperature Profle Comparicon: $Q=20 \mathrm{w}$. 12

Pact

4

5

7

9

10

13

15

15

18

10

43

47

49

52 
Los Alemos Technical Ascocietes, inc.

\section{LIST OF FIGUines \\ (Contiaued)}

17 stady state Temperature Profle Comparicon:

18 Experimental-Numerical Comparicese of Temperature a a Function of Tine at Four Rediny 8pacad Thernocouple Locations: Day 1.

10 Experimental-Numerical Comparivons of Tepperature a - Function of Time at Four Radinlly spaced Thermocouple Locations: Day 2.

20 Thermal Conductivity of ane Meter Cube of Rocksalt from Misstesippl Chenical Co. of 8. E. New Mexico Potanh Mine - Latest Datu.

21 8ection of Salt Block I showing Locations of Sample Removal.

22 Percent Woicht Loss as a Function of Tamperature from Previously Unheated salt Block I Baples (Ref. 17) 


\section{LET OF TADLES}

\section{Table}

Nuber Tits

Pere

I Rolationehtp Betmeen Instrumeatation Chand and Dherwocouple Nuber

II Evaluation of Influence of Therrecouple Hole Filler Motorial

III Relationship of Sxperimentel and Jumerical Identifiers for Solncted Points in Balt Block I

IV Eit Conductivity pata

V Cosparison of Masured and Computed Temperatures: $Q * 1000 \mathrm{~W}$, (Insulated)

VI Comparison of Mansured and Computed Temporatures: $Q=525 \mathrm{~W}$, (Insulated)

VII Comparison of Masured and Computed Temperatures: $Q=24 \%$, (Uninblilated)

VIII Comparicon of Masured and Capjuted Teaperatures: $Q=520 \mathrm{~W}$, (Uninsulated)

IX Comparison of Masured and Computed Temperatures: $Q=750 \mathrm{~W}$, (Uninsulated)

$X$ Comparicon of Masured and Computed Temperatures: $Q=1,200 \mathrm{~W}$, (Uninsulated) 
Los Alanos Sechnical Areciates, Inc.

\section{Rexmontroorimes}

The work of the many wIP eupport orgenisatlons who conducted and apported thir experiment if pratefully acknow1edged. rowe, but by no mene hl, of the Individual tho worked on this experinent are cited in the list of references. The progrem manegement for the experinente was provided by Allen sattler, Org. 4512, and Falier Melson, 1124. Analyses were performed by Dave cartiling, 5511. The salt biock $I$ and supporting experinente were conducted by nuerous individuals in Organization 1100 including Jin Merlmoyle. Wayne Cook and Ron Ering. 
Los Alsmos Techical Assoclates, Inc.

\section{Ansucr}

es.

A series of laboratory experimente has been coppleted ac sandia Laborator 1es to provide en understanding of the etendy strite and trandent thetunl reponce of a large selt blook conteaining in internal bat couros. In this report, details of the experinental program are prevented aleas with results of related efforte, ouch a thermal conduotivity experimente, done In support of the heter experimente (Init blook I). Finite -1enent temporature field prealctions, both tranolent and ateady state, are parformed utilising the coroy nonlinear heat conduction progrem. Comparisone of experimental and theoretical result are generally quite good. 
Los Alanos Technical Associates, Inc.

\section{Excrion It}

\section{InThOOUCTION}

A series of laboratory experiments has been parformed at sandia Iaboratorite over the past 2 yr for the purpone of generating date and information relating to the storage of radioactive wates in balt. The experinents were conducted as part of the experinental progra for the vaste Inolation pilot Plant (WIPP) and serve as a prelude to subsequent in-eitu experinents in the WIPP. These experiments have either been performed directly on what is known as salt Block I or have been parformed in uupport of the salt Block I experinenta.

The apecific objective of this series of experiments were

(1) Te develop a method to sinulate the hating due to an emplacement of high-level waste in salt.

(2) To deternine if the thermal conductivity of bedded alt is isotropic.

(3) To evaluate nethods for backfiling of instrinentition holes in the eart.

(i) To evaluate corrosion in a heat field in salt.

(5) To obtain experience In Inatrumenting bench scale semples of ealt prior to performing an in-aitu experiment.

(6) To obtain some prelininary data on brine aigration in ealt.

(7) To develop and provide analytical tools which can take account of heat lond emplaced in salt. 
Low Alsos Technical Associates, Inc.

Docuentation of the various phases of the experinental programe, as wil as the later theoretical correlations, has to date been accopplished in the form of aeries of Internal sandis Laboratories correspondence see References I through 7). It 1 the purpoes of this report, therefore, to combine these into a single reference.

In the Eollowing ecetion, a prelininary est of wall-scale heater and thermel conductivity tests is described. These tests were performed prior to running the full-gcele ealt block experiments dewcribed in section VI. Mlo presented in section vi are results on corrosion and water lose in a field of heated salt. Kext, the theoreticel fintte elenent odeling detalls for providing temperature profile predictione are described in section VII, followed by representative experimental-theoretical correlations with salt Block I experimental data. A simary of results and conclusions conpletes the body of the report. This sumary indicates how the above objectives mave been net. 
Los Alemos Technical Asecciates, Inc.

\section{SECTION $v$ \\ PRELIMIARY BAALL-BCAIE EXPERINENTS}

\section{A. Bcaled Balt Block Heater Teat}

Before the full-scale thermal test was performed, a scaled heater/salt block test was perforned using a sienll core fron the first calt block. The scalad teat utilined a reometry sthilur to the large block. A vertical exction of the ecaled heater experiment is shown in Firure 1. For purposes of comparien, a siliar vertical section of the Lerge Balt Block Heater Experinent No. 1 is shown in Figure 2. It can be seen that silight differences do exist, wheh as in relative dimensions of heater and salt block. However, it is obvious by inspection of the two experimental configurations that, in a scaled sense, transient and steady state thernal bebavior should be at last qualitatively the same.

Two shoplified scals model tosts wore performed. One scale model was heated Eradually over a period of 4 daye to a peak temperature of $325^{\circ} \mathrm{C}$, while the other was rapidly hated to $360^{\circ} \mathrm{C}$ is 30 min. No difficultios (such os esvere decropitation of the salt) were encountered in either exporiment durine the tost iteolf as woll as after the test upon sectioning the models.

\section{B. Salt Thereal Conductivit Magurements}

In eddition, bofore performing the full-scale heater experiment, thernal conductivity messurements were performed on a rock salt sasple taken fron the larce salt block to be subsequently used for the full-ecale therenl teat. The anple was furnished by the Nississippi Chenical Company and was taken tron thoir. potash mine located in southeast New kexico.

The particular semple taken for theralal conductivity measurements was sectioned from a core romoved from the large sult block for placement of the cylindricul heater shown th Figure 2. 


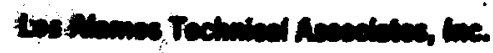

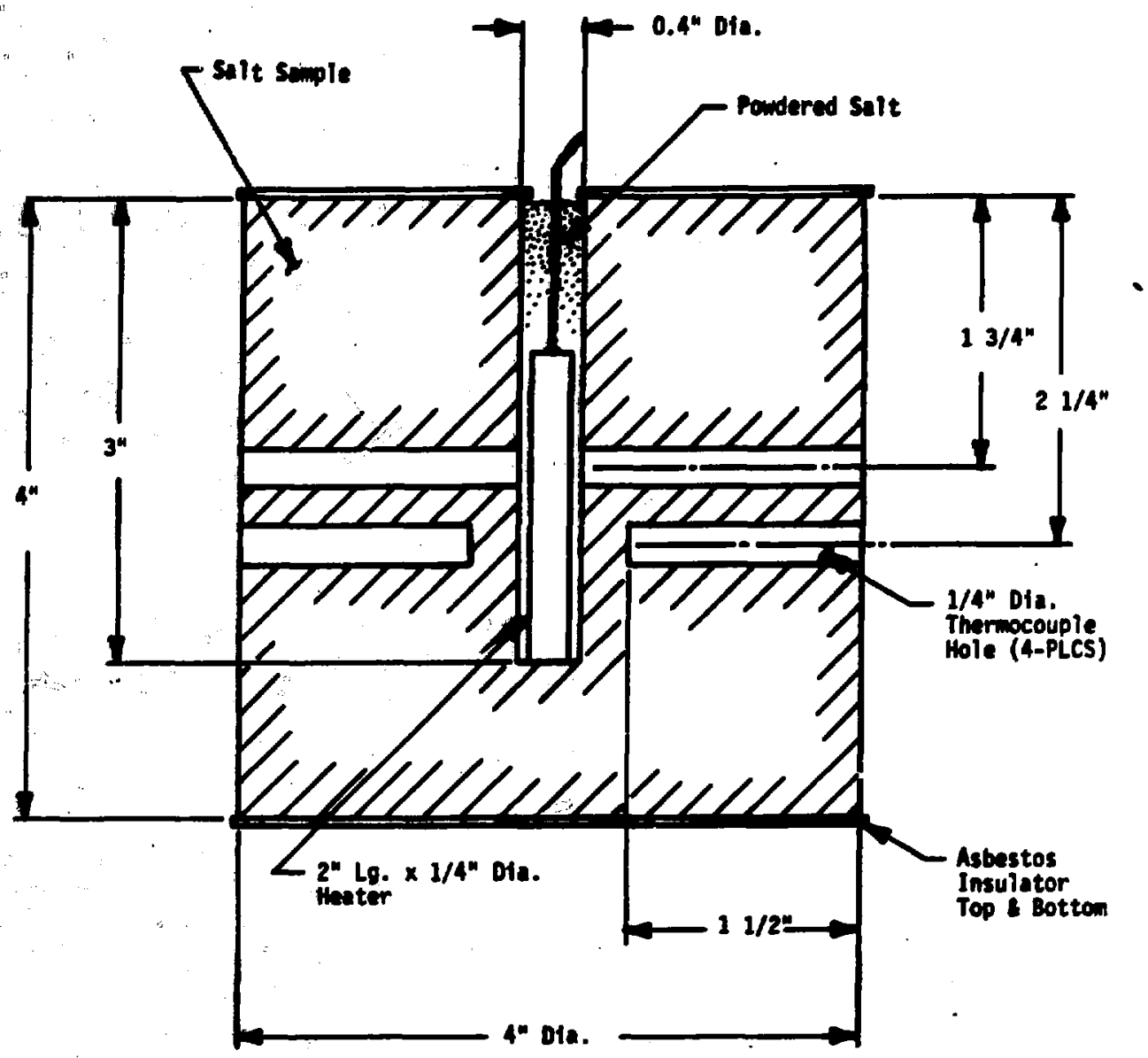

Figure 1. Vertical Section of Scaled Hater Experiment. 


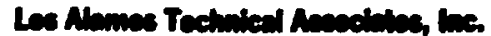

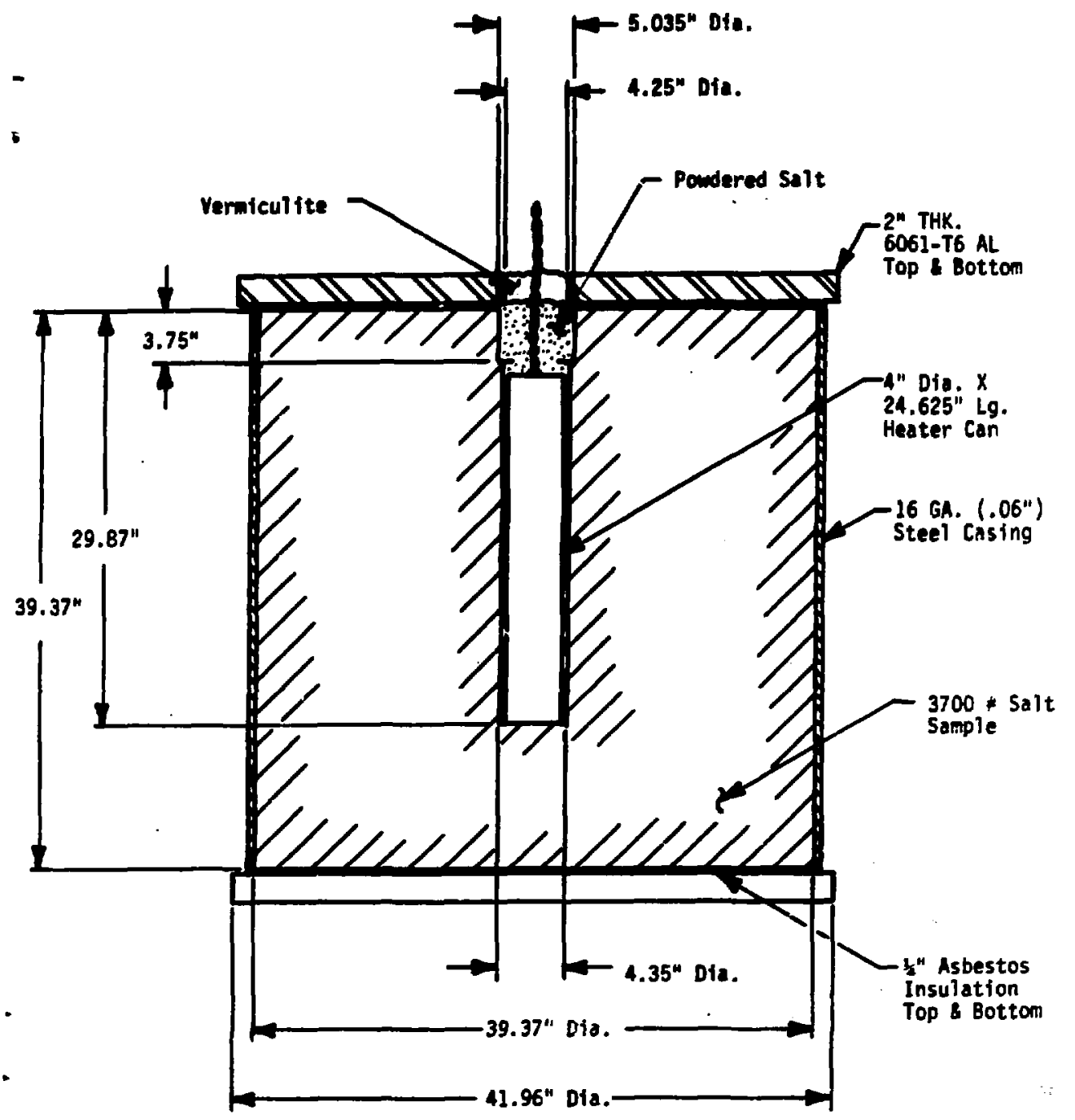

Figure 2. Vertical Section of Large Block Heater Experiment Muber 1. 
Los Alemos Technioal Associndes, Inc.

The thereal conduettuty recordad 2 a function $\alpha$ temperature is

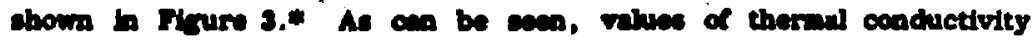
are in the vicialty of $3 \mathrm{w} / \mathrm{m} \mathrm{x}$. The crecks beated at the cade of the core were rwoved when the exple we prepared. The thermal cosductivity values throush which the curve is drawn in Figure 3 were obtained dustas the batting phace. Oxe data point (shown in Figure 3 with a Arfereat aybol) we taken during the coolfos phese after the carliter rudinge were taken. The slightly (108) bower value obtained at this later tere na be due to water bes.

Hownerer, see section VIII, subenction E for a discussion of nore reomety obtelined bedded salt values. 


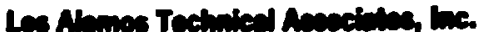

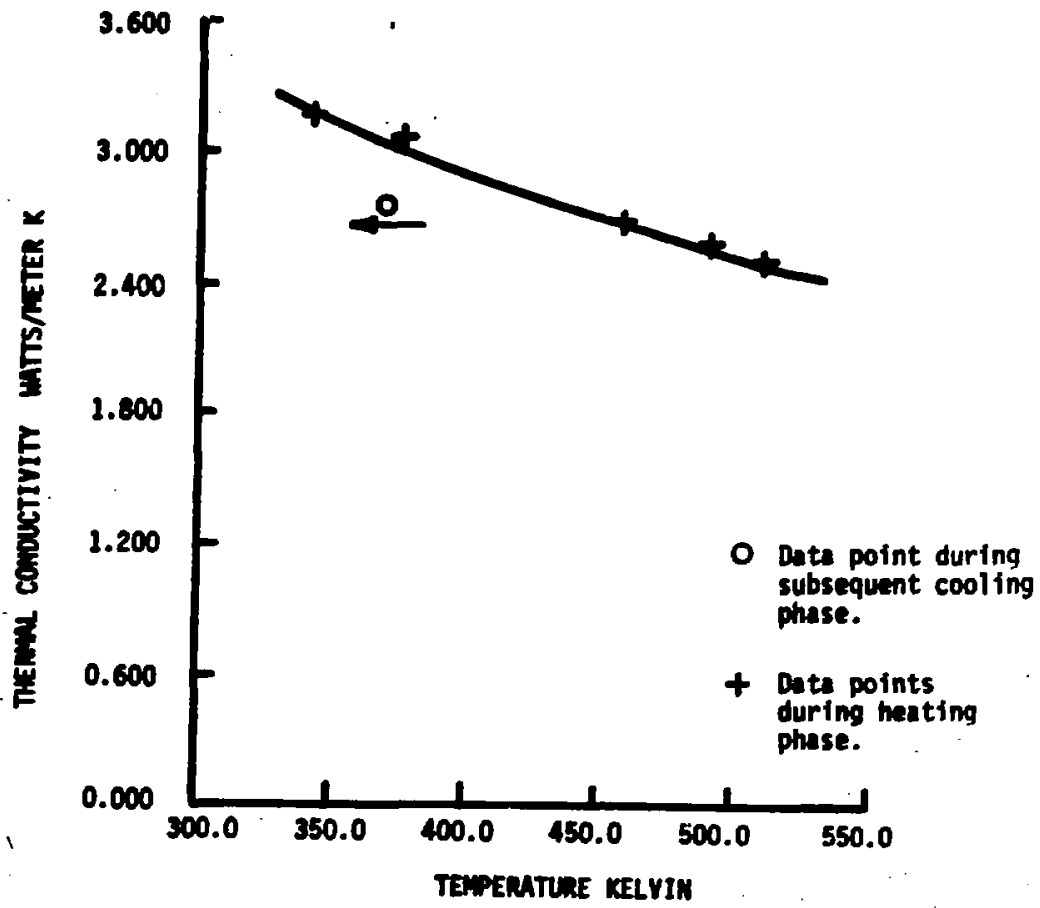

Figure 3. Theneml conductivity of llocksalt from Mississippi Chemical Co. S.E. Mew Mexico, Potash Mine. 
Los Alamos Technical Aseociates, Inc.

\section{BRCTION VI \\ SALT BLOCK TEST I - EXPEANENTAL DLTALL AND RBSULTB}

The Larce Salt Block Heater Ixperinent No. 1 was perforeed in a annner atailar to the sculed heater expertent described in the previous ection. Differences between the experinentel configurations of full-scale (Firure 2) and small-scale (Figure 1) tests are worth mentioning at this point.

While both test setups include an asbestos insulator placed on top and botton of the cylindrical sanple, the large salt block aleo included heavy aluminum plates placed at the cylindor ends. These plates are held in place by large bolts running outolde the sample and connecting the plates. Aleo, the larce tost is circunforeatially confined by means of an outer steel cylinder.

The salt block at two stages of machining is as shown in Figures 4 and 5. Firure 4 shows the inttal turning process used in forming the right circular cylindrical specimen while Fisure 5 shows the reanval of the cort specinen, part of which was used for the thernal conductivity measurements reported in the previous section. The resulting axial hole in the salt block was subsequently used for brater placement followed by backfilling.

\section{A. Instrumentation Utilized}

The Salt Block I test was instrumented with a total of 51 thermocouples. The purpose of this large number of thernocouples was to define the thermal fiold created by the internal heater. In addition, four stress meters were utilized (rigid inclusion type).

Locations of 49 of the thermocouples are as shown in Figure 6a*, while placement of the stress meters is as shown in Figure 6b. Details of thermocouple bocations within or on the henter

* Note that the last two thermocouples nubered 58 and 59 are bocated on the top ahininum plate at two radial bontions and therefore are not shown in Figure 6 . 
Los Alamos Technical Associates, Inc.

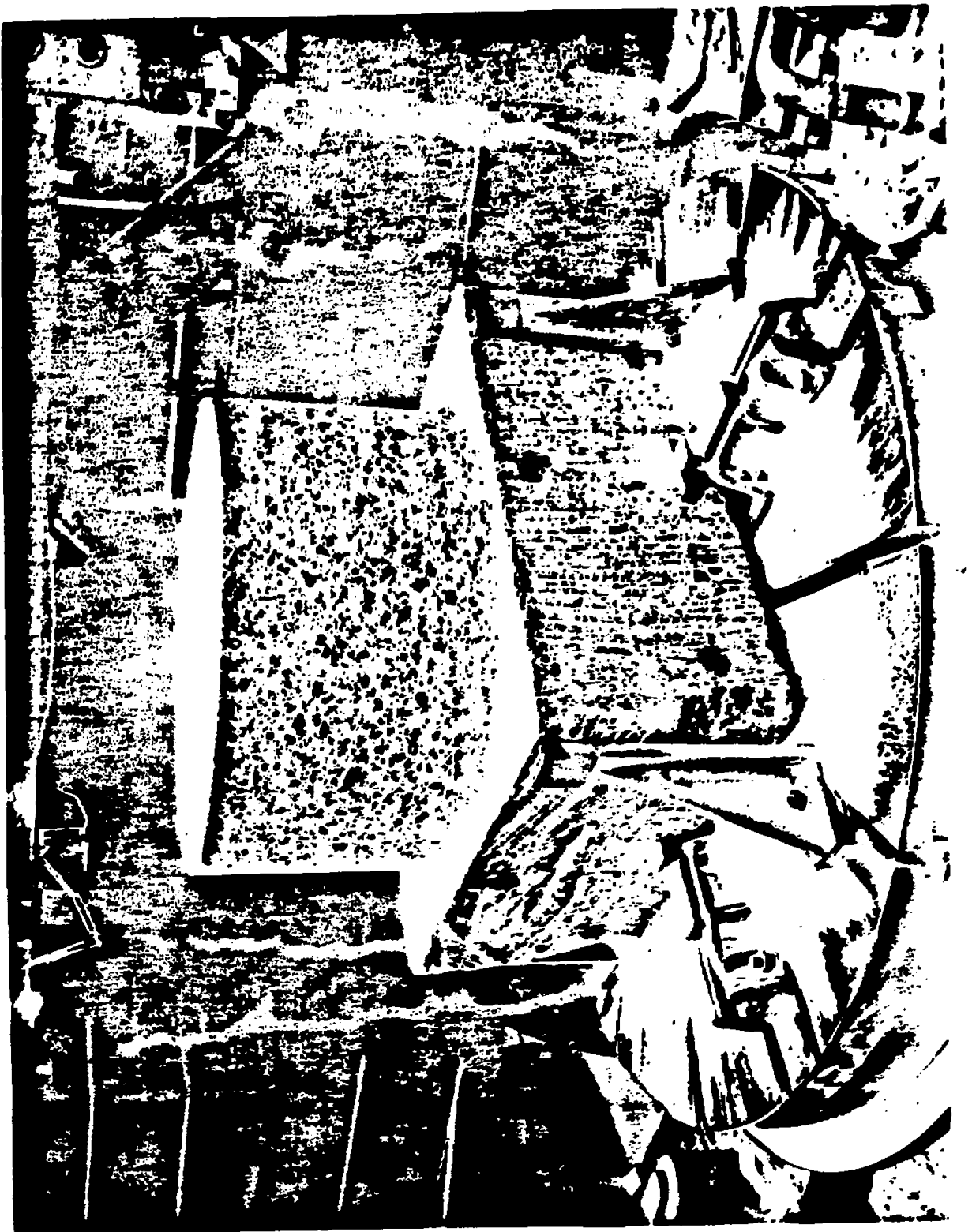


Los Alamos Technical Associates, Inc.

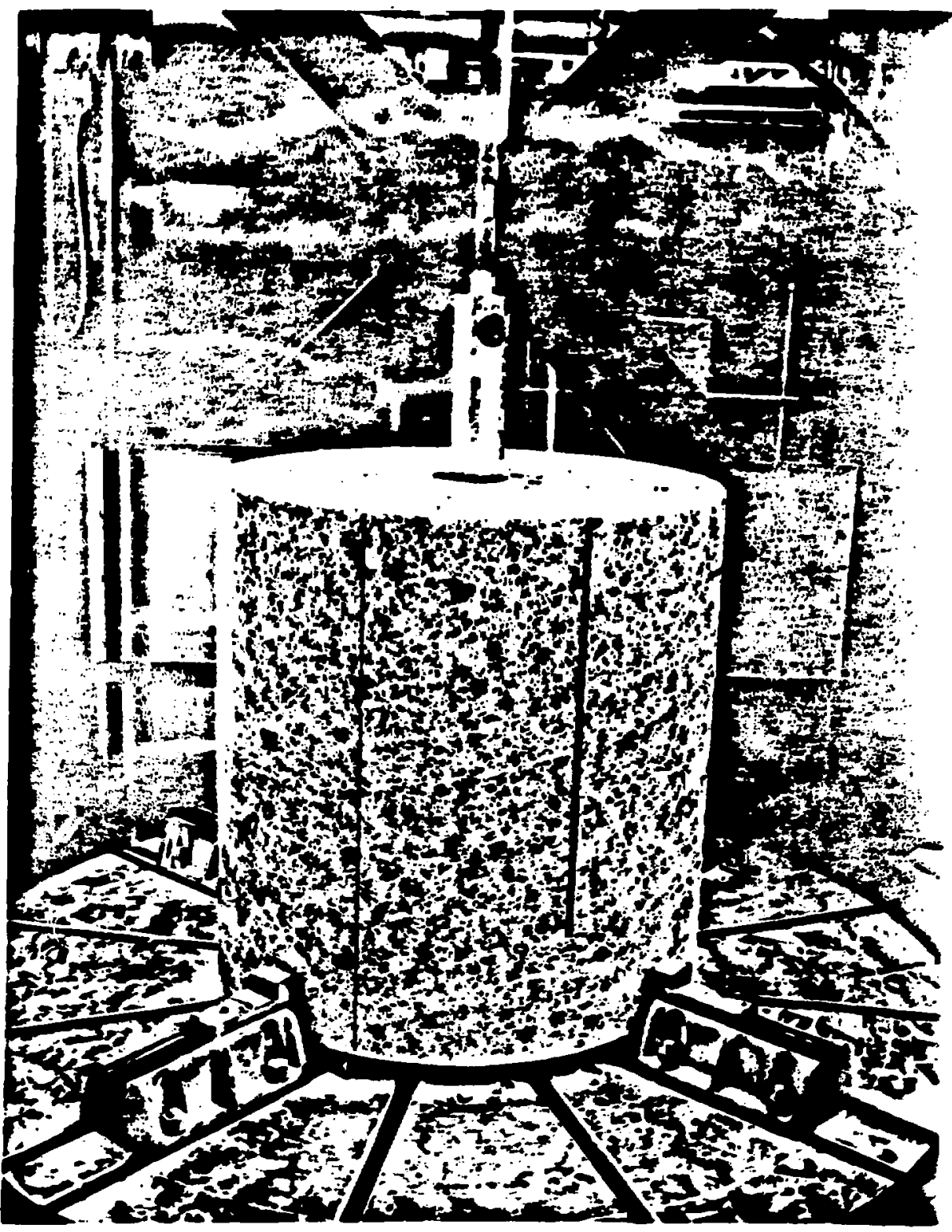

Figure 5. Cutting of Core Specimen (and Heater Hole) from Salt Block I 
Los Alanos Techniod Acecoindes, Inc.

\section{METER DIA. $\times 1$ METER HICH}
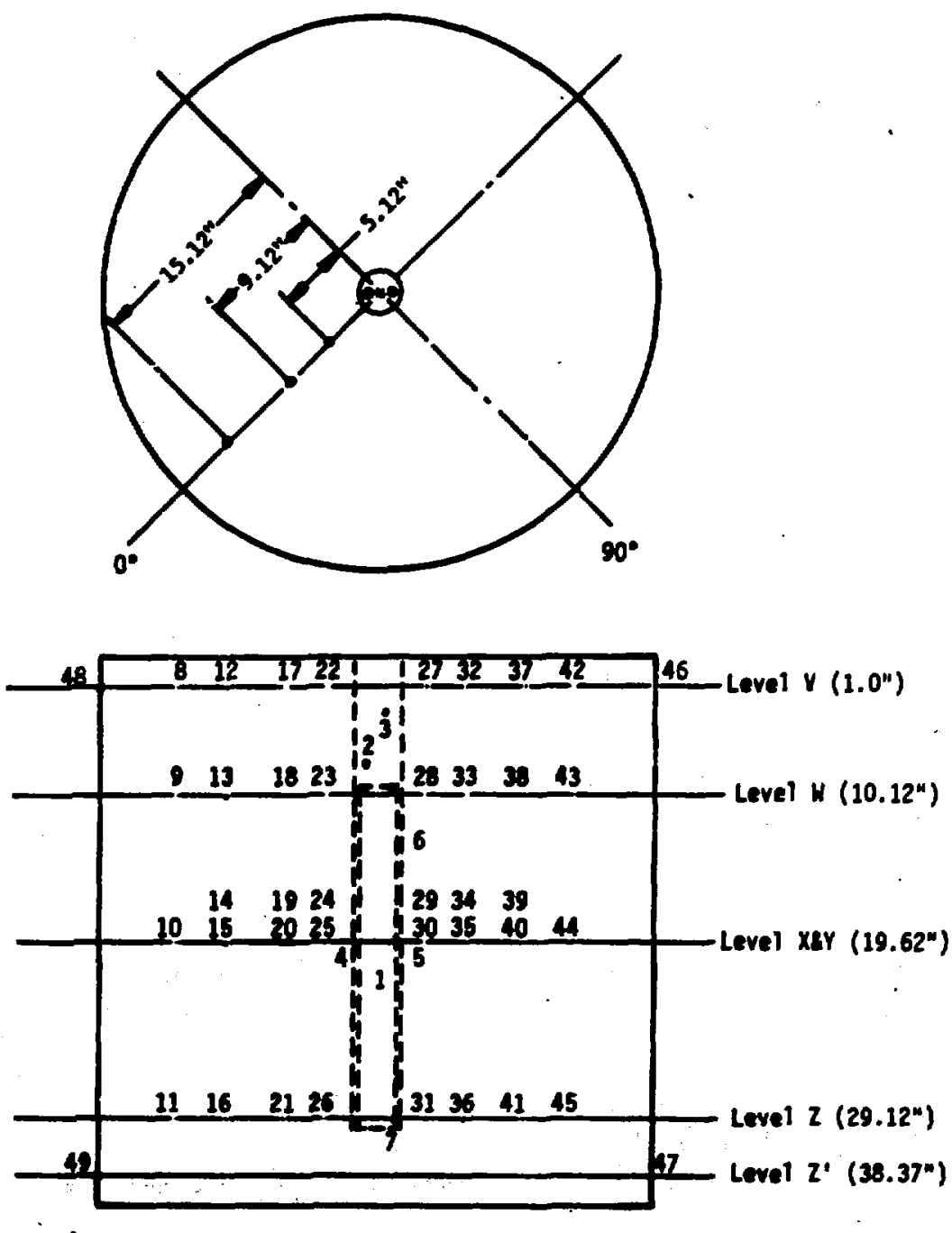

Figme Ga. Leentions of Thernocouples in Salt sleck 1. 


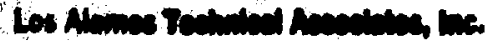

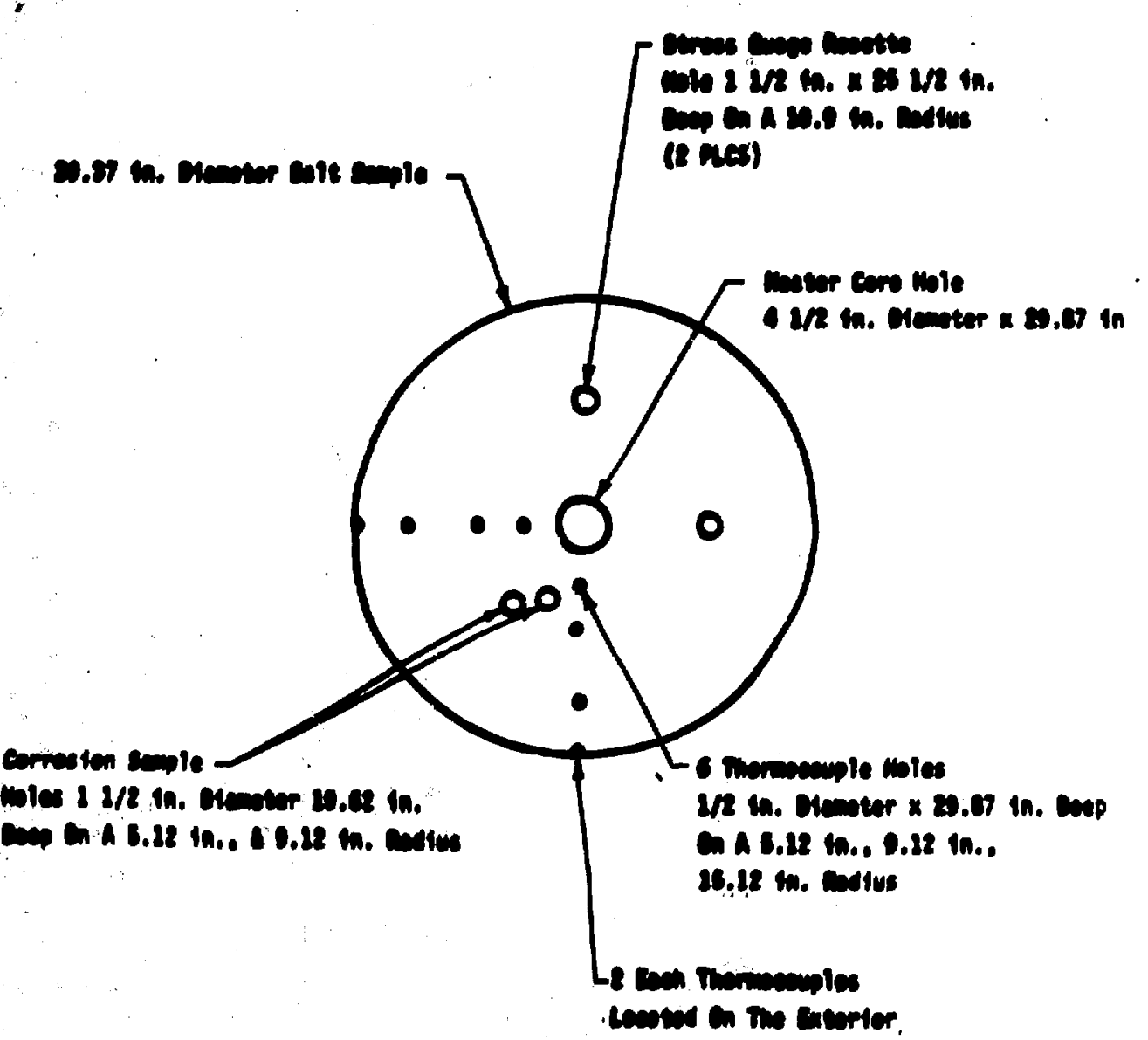

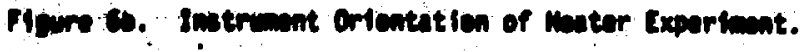




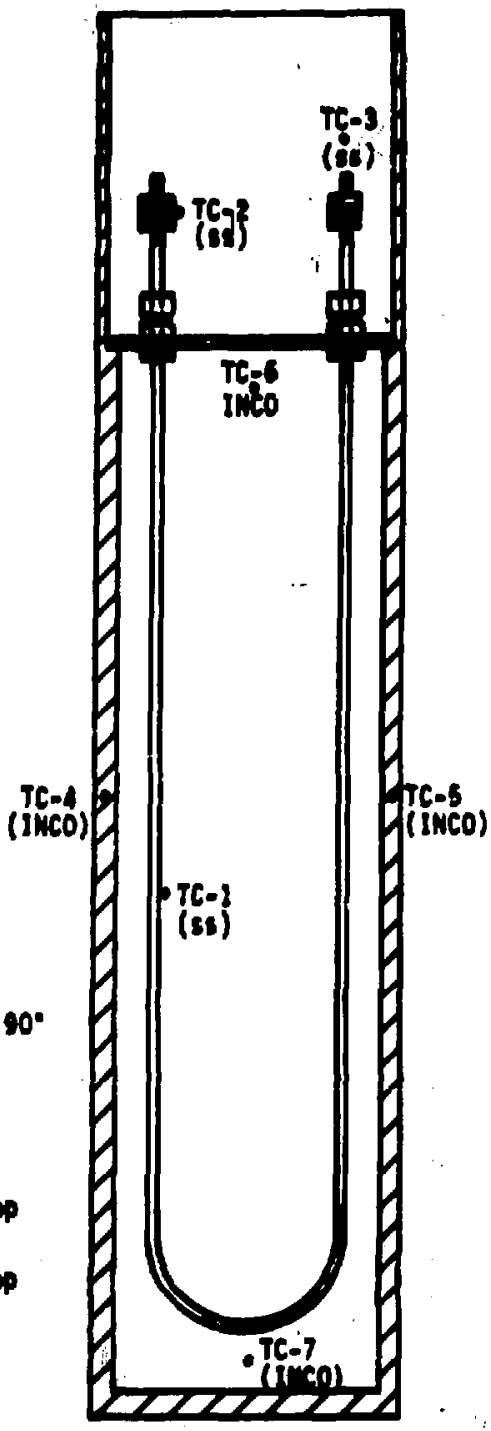

Wot to scale

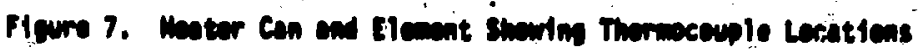

TC-2 Hoster Element ot $0^{\circ}$

TC-2 Hoster Clcoment Nut at $0^{\circ}$

TC-3 Hester Insulator lasd at 90"

TC-A Heater Con Ext Mid Polnt at $0^{\circ}$

TC-5 Hester Can Ext Wid Point at $50^{\circ}$

TC-S Hater can Ext I" Prom Tep at $30^{\circ}$

TC-7 Hater Can Ext 8" Prom Top at $100^{\circ}$ 


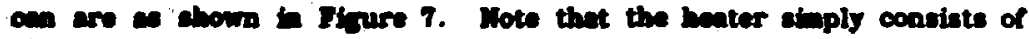

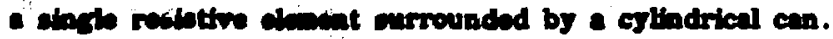

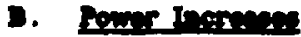

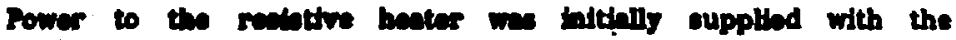
droultry so shown is Ityre 8.

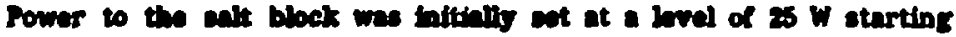

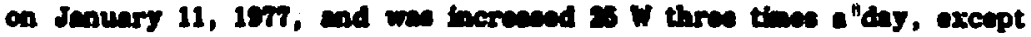

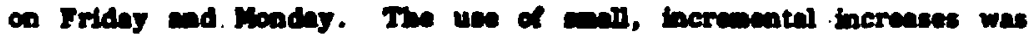

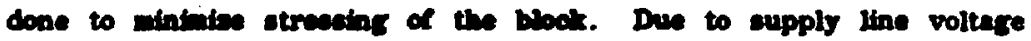
variation, come drop in power wes expexisesed durtas morning hours

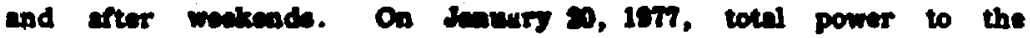

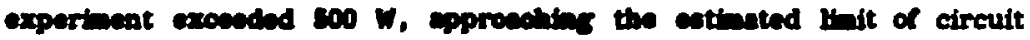

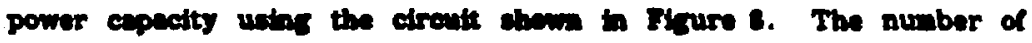
berwaes of pewer we raduond to onoe a dy on Jmuary 25, 1977. By

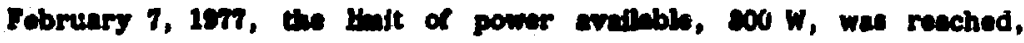
neconeitatiac a chace poner elreult ecafisuration.

The power choutt eubequenty utilined is w thown in Figure 9.

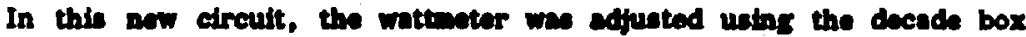
bhown to provide the ene power reading st the sene voltage bvel as was uead in the elronit of Figure 8 . The new configuration utilises an

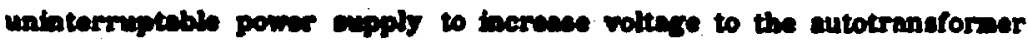
sad redues power verietions des to the voltege changes. The

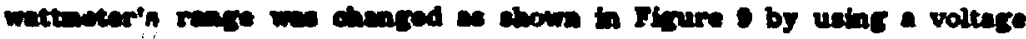

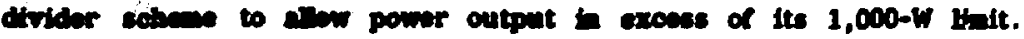

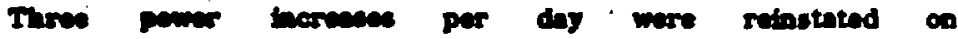

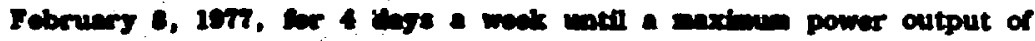

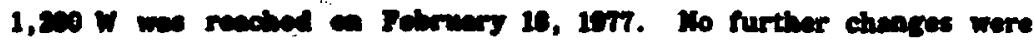

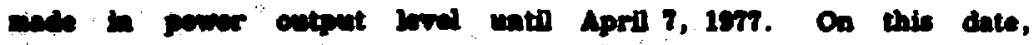

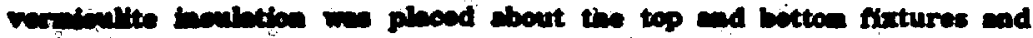

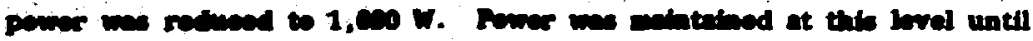

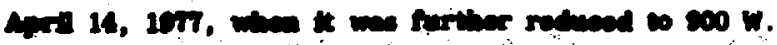




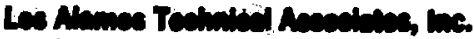

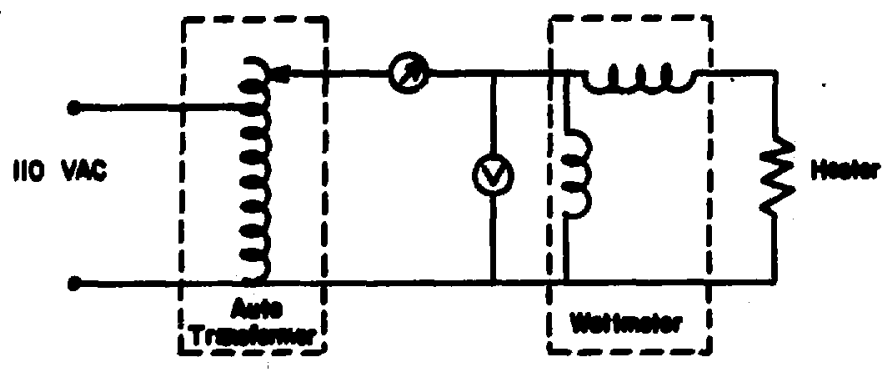

Figure 8. Initial Transformer Circuit for Pomming Resistive Hester.

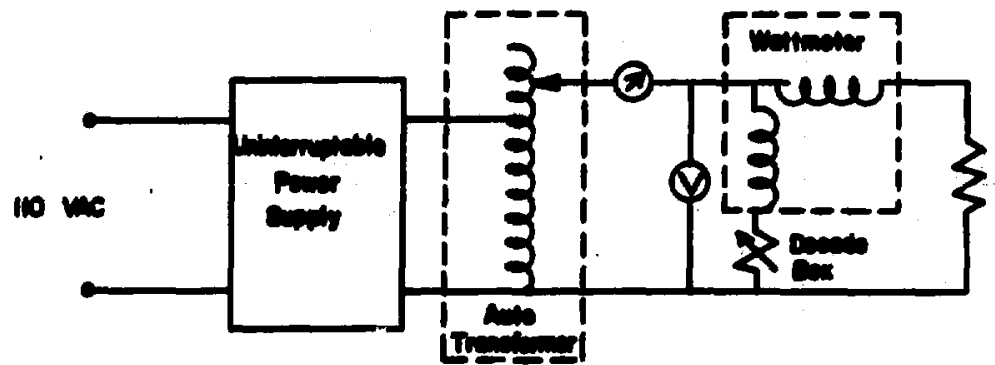

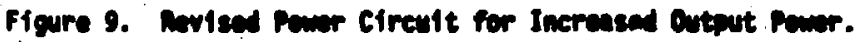


On Aprti 18, 15\%, power we reducad to $525 \mathrm{~W}$ in approxinatley $100 \mathrm{~W}$ increveats and the orighal trenaformer chreult (Figure o) was

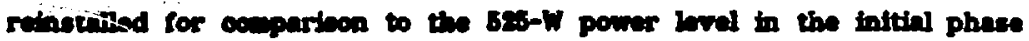
of the experiment.

Tos Inlt Dbok I eppormat was torminated on April 18, 1977, by dropplar power in $100 \mathrm{~W}$ thermenats.

\section{c. Dew Date of fert Plook Teat I}

For completenoss, it abould be noted that the thermocouple numbers are not the sene $c$ the chanal numbers utilised in the orisinal rew data. Corresposdting tharmocouple numbers and channel numbers are as mdicated in Table I.

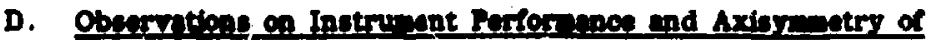 whind ne}

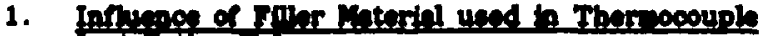 InITighose}

As shown in Fente 10 (aleo compare thernocouple beations shown in Ifoure 6), thermoseople holes are drilled parallel to the longitudinal axts of the cylader. One concern we that the anterinl uead to isecketil thase thernocouph boles following thermocouple plecenent could provide a sifniflemt variation in enecurnd temperature reading. For this receon, one sddutioal objective of the test was to compare two

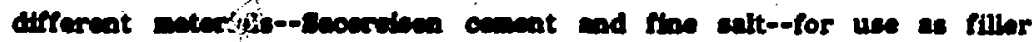
eaterinle in thermocouple tastallation boles.

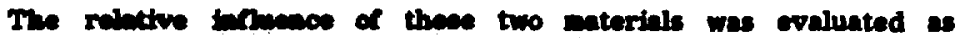
tollowe:

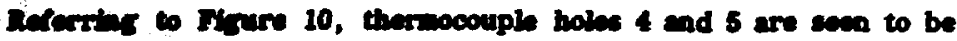

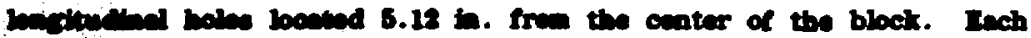

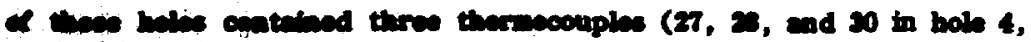

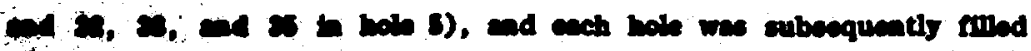


Los Alamos Technieal Areocieten, Inc.

\section{TABLI 1}

RHATIONOHP DETWMA IISTRUDLWTATION CHANNEL AND THLANOCOUPL NUTBRR

\begin{tabular}{|c|c|c|c|}
\hline $\begin{array}{l}\text { Channel } \\
\text { No. }\end{array}$ & $\begin{array}{l}\text { Therrocerples } \\
\text { Io. }\end{array}$ & $\begin{array}{l}\text { Chmanal } \\
\text { No. }\end{array}$ & $\begin{array}{c}\text { Thermocouple } \\
\text { No. }\end{array}$ \\
\hline $\begin{array}{l}005 \\
008 \\
007 \\
003 \\
009 \\
010 \\
011 \\
012 \\
013 \\
014 \\
015 \\
016 \\
017 \\
018 \\
019 \\
020 \\
021 \\
022 \\
023 \\
024 \\
025 \\
028 \\
021 \\
028 \\
028 \\
080 \\
031 \\
032 \\
033 \\
034\end{array}$ & $\begin{array}{r}1 \\
2 \\
3 \\
4 \\
5 \\
6 \\
7 \\
8 \\
9 \\
10 \\
11 \\
12 \\
13 \\
14 \\
15 \\
18 \\
17 \\
18 \\
19 \\
20 \\
21 \\
20 \\
23 \\
24 \\
25 \\
23 \\
27 \\
20 \\
29 \\
30\end{array}$ & $\begin{array}{l}045 \\
048 \\
037 \\
038 \\
039 \\
040 \\
041 \\
049 \\
043 \\
044 \\
045 \\
045 \\
047 \\
048 \\
049 \\
050 \\
051 \\
0.52 \\
035 \\
002 \\
005\end{array}$ & $\begin{array}{l}31 \\
32 \\
33 \\
34 \\
35 \\
36 \\
37 \\
38 \\
39 \\
40 \\
41 \\
42 \\
43 \\
44 \\
45 \\
46 \\
47 \\
48 \\
49 \\
58 \\
59\end{array}$ \\
\hline
\end{tabular}




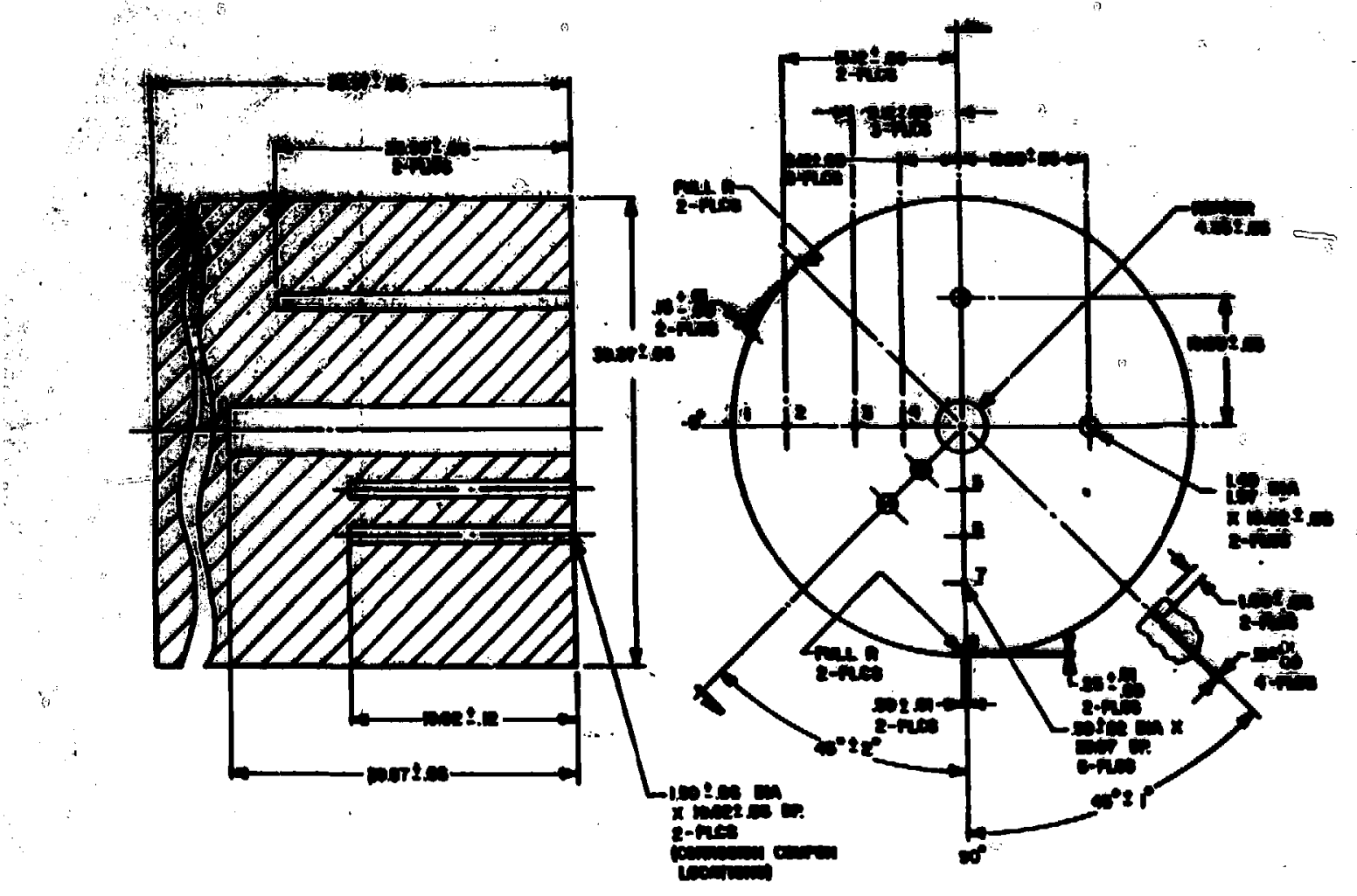

Figure 10. Salt block I Dhmansions Including Thermocouple bole Specifications 


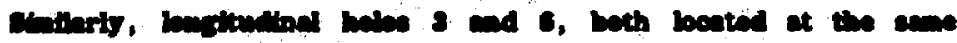

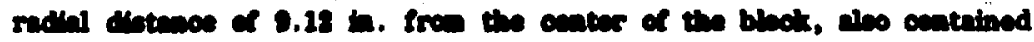

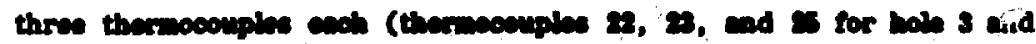

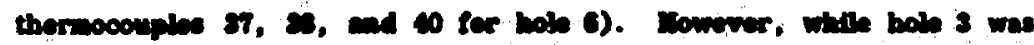

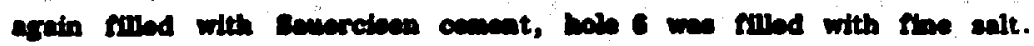

A reprecentative emple of the temperiture dat recordad at the total of 12 thereconiples bouted in these 4 holes is chown in Table II

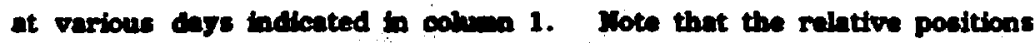
of the varions thecmocurite can be deduced frem Fizures 8 and 10. For simplicts, the firet entry under ench of the four holes correaponds to the thermocouple bented near the top of the bater; the eccond entry correpponds to the thermocouple bonted sear the center of the heater; and the thind catry coxrespoeds to the therwocouple located near the botten of the henter.

Ieferring to Tabl II, a compariecen of respective thorwocouples in

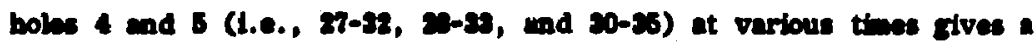
meavure of thermocouple veriation at the "anos" axial and radial pontione in the sult blocks with the sene thermocouple hole filler paterial. Os the ether hend, compuriece of reepective therwocouples in

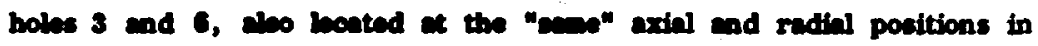

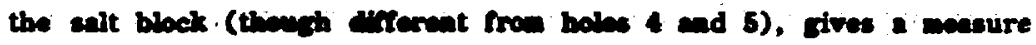
of variation intoduced by vuryes the hole fillar anterial.

As can be ene by inpection of Trble 11 , the oaly significant

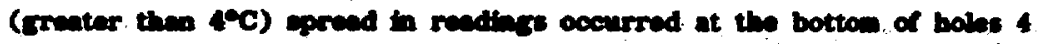

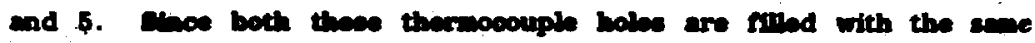

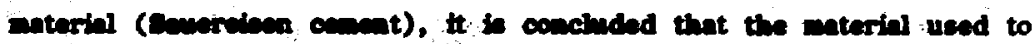
fil the therwocouph bole ad bot aifect the readinge.

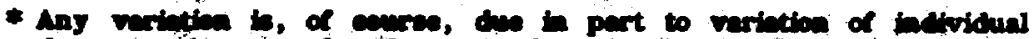

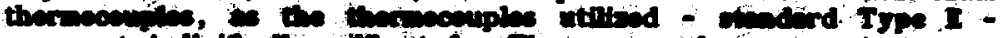

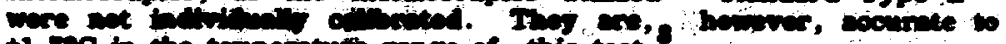

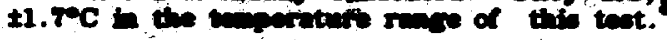


TABLE II

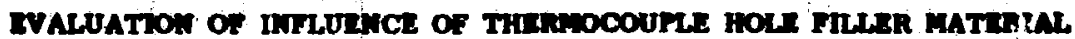

\begin{tabular}{|c|c|c|c|c|c|c|c|c|c|c|c|}
\hline 2 & 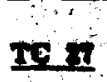 & tc i & IC 3 & TC 32 & $\begin{array}{l}\text { Tole } 5 \\
\text { TC }\end{array}$ & TC 3 & TC 2 & $\begin{array}{l}\text { Hole } 3 \\
\text { TC } 23 \\
\end{array}$ & TC 25 & TC $x$ & IC: \\
\hline 1 & 19.0 & 18.2 & 17.9 & 10.5 & 18.3 & 18.0 & 18.4 & 18.2 & 17.8 & 18.8 & M.E \\
\hline$B$ & 20 & 5.1 & $\boldsymbol{x . 9}$ & 5.3 & 3.3 & 35.7 & 32.4 & 38.7 & 31.6 & 3.8 & x.e \\
\hline 10 & s1.e & 01.4 & 51.9 & 83.1 & 61.6 & 54.2 & 48.4 & 47.7 & $\$ .1$ & 4.8 & $\mathbf{s}$ \\
\hline 18 & $\mathbf{m . 8}$ & r.8 & ED.5 & 00.5 & 71.2 & 62.4 & 4.5 & 54.0 & $\omega .5$ & $\omega .0$ & EA.7 \\
\hline$\infty$ & 0.8 & 7.0 & 04.8 & $\mathbf{0 . 0}$ & $\boldsymbol{\pi . 0}$ & 6.2 & 51.8 & 83.4 & 58.3 & 82.2 & 5.7 \\
\hline 8 & $\boldsymbol{c o s}$ & 6.7 & 71.3 & $\mathbf{\omega . 1}$ & 6.6 & 75.0 & Es.0 & 63.6 & 50.9 & 85.0 & Q.4 \\
\hline 30 & 70.6 & 102.0 & 4.5 & $\mathbf{7 . 0}$ & 102.0 & $\boldsymbol{\omega . 0}$ & 4.1 & 74.2 & 6.7 & en. & 7.1 \\
\hline 25 & $\boldsymbol{\omega . 1}$ & 118.1 & 55.6 & $\mathbf{m . 1}$ & 118.3 & 101.0 & & $\boldsymbol{9 . 4}$ & 73.0 & n.t & 9.3 \\
\hline 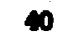 & 100.8 & 140.2 & 112,3 & 108.1 & 190.0 & 119.0 & 8.1 & 97.3 & 4.6 & 81.3 & $\mathbf{3 0 . 5}$ \\
\hline 45 & 101.7 & 138.0 & 110.4 & 100.2 & 153.0 & 117.3 & 0.5 & ร5.6 & 03.5 & 79.6 & 5.0 \\
\hline \multirow[t]{4}{*}{ 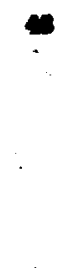 } & $\boldsymbol{\pi}$ & 133.6 & 100.3 & 36.5 & 134.0 & 113.4 & 76.9 & ย1.๑ & 7.8 & 7.5 & 91.7 \\
\hline & \multicolumn{5}{|c|}{ Mistad (Hole 4 - Hole 5) } & \multicolumn{5}{|c|}{ Maxianom aT (Hole 3 - Hole 6) } & \\
\hline & & \multirow{2}{*}{\multicolumn{2}{|c|}{$\begin{array}{l}\text { TC } 27-\text { TC } 32: \\
\text { TC } 20 \text { - TC } 33:\end{array}$}} & $1.7^{\circ} \mathrm{C}$ & & & & \multirow{2}{*}{\multicolumn{2}{|c|}{$\begin{array}{l}\text { TC } 22-\text { TC } 37: \\
\text { TC } 23-\text { TC } 38:\end{array}$}} & $0.7{ }^{\circ} \mathrm{C}$ & \\
\hline & & & & $0.4^{\circ} \mathrm{C}$ & & & & & & $0.8^{\circ} \mathrm{C}$ & \\
\hline & ; & TC $\mathbf{3 0}$ & TC 35: & $6.9^{\circ} \mathrm{C}$ & & & & TC 25 & TC 40: & $1.1^{\circ} \mathrm{C}$ & \\
\hline
\end{tabular}




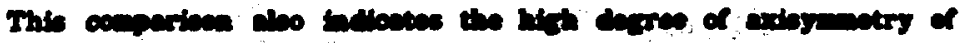

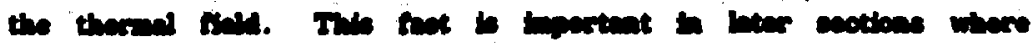

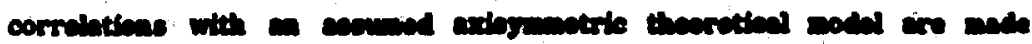

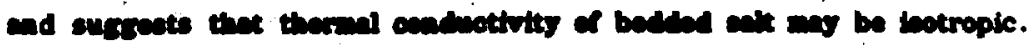

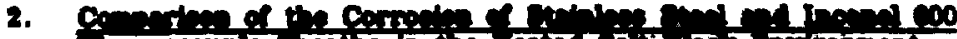

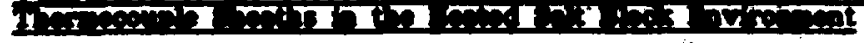

After the beater wes chut of in the Ealt Blocki I expertment,

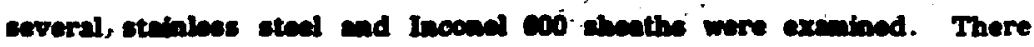
wes no obrious corroaton of etther moterial.

\section{Itrosineter Rexults}

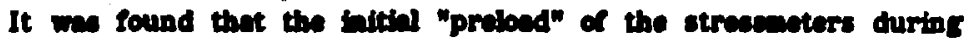
this tast could not be melitainad. In particular, at $500 \mathrm{~W}$ hput and 10 days bto the teet, all the strueventers wore for al pretical

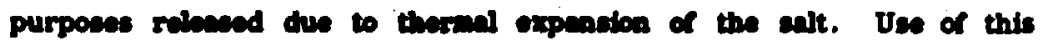
rield tochusion-type strescanter is therefore not recommended in future experimate of this type. Ischusion of the strenemeters did, however, provide tempereture bebevior of the instrumentation at acro strese bevels.

\section{Carrovin canpons}

The corrocivity of exveral netal coupons wes testad durtes the

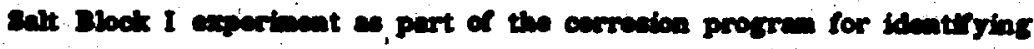

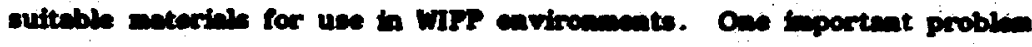

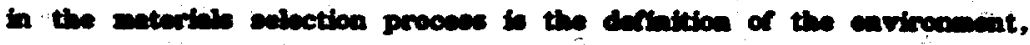

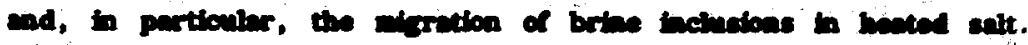

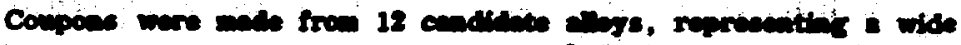

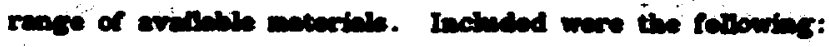

1. Trianim.

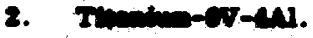

2. Enomilloy C-25. 
4. Inomat-600.

B. Zirenainin.

B. Ereaing-2.

7. Zrealog-4.

8. Cerpenter nocb-s stativese steal.

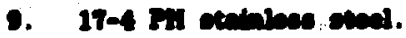

10. 20-20 birws.

11. Aluminum cosi.

12. 1018 carbon steal.

Nowe that thaie alloys are liated th order of expected increasing corrosivity, scoording to a brise corrosion Hternture survey.

Eech coupon wes anchined to be $2.84 \mathrm{~cm}$ per stde by $0.64 \mathrm{~cm}$ thick. Oas surtece of cach coupon was nirror polishod and photosraphed so that a cubsequeat qualitative visual daternination of any corrosion could be made. Jinally, ench coupon was woished to the nearect 0.1 ms.

As shown to Figure 6b, a $8.8 \mathrm{~cm}-(1.5 \mathrm{tb})$ dinmeter hole (asmple hole nearest the heater in If(gure $(b)$ wee bored parallel to the heater holde and $7.5 \mathrm{ar}$ from the outaide edre of the beater iteelf. The hole bottom was located at the vertical nidplene of the salt block. The coupons mare placed flat in the bole with epproxtantely $1.5 \mathrm{~cm}$ of aruched ealt between each one to prevent any corrosion secelerating calveic afects. Aleo the coupons were ordared such that the nost rececture wre on the bottom.

Conpens ware pleced in postion on Hownuber 9, 1976 (recall that the mater expertibit was begun on Jenunry 11, 1977, and terminated on Apre 18, 1977). The mecured therwal hiotory at the botton of the

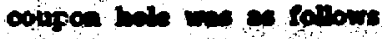




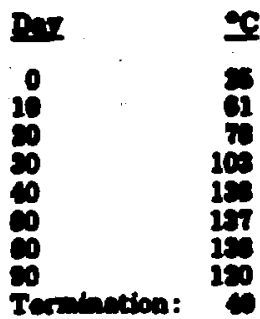

A steep thereal eredient axisted solng up the bole with the tenperature at the top ampla legsiar the botton by 20 to $80^{\circ} \mathrm{C}$.

Laboration extenination of the coupons followits the test revealed no corrosion of an empls. All coupens (as well as the platin carbon

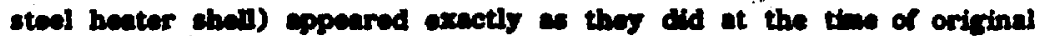
pleckent, except for the ro-so braes, 1018 sted, end ose of the stainless steal coupons. Fech of these thres had a thin, sonadberent,

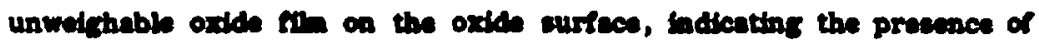
molsture.

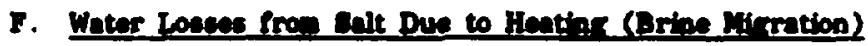

Two diforent sots of meneurwents of water bos due to hasting were end with saterial from salt Block I. In both experimental progrems, thres types of enoples were utalined: senples near the ceater (highest tomeperature theld), expoles moar the will (bowest temperature thidd, and semples which had so prior hiatory of heating.

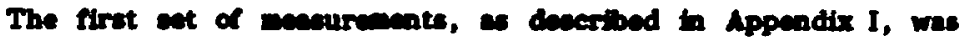
obteined by the bations of semples for three daye at seorc. The

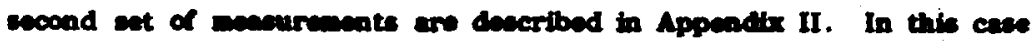
beating wes at $8009 \mathrm{C}$ and wes for a twalve day durntion. 


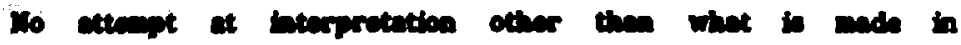

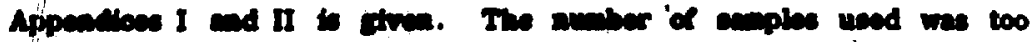

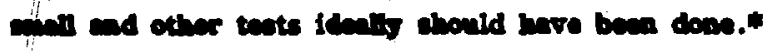

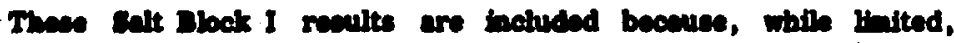

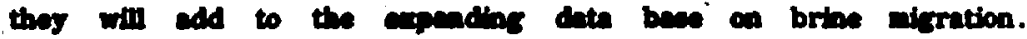

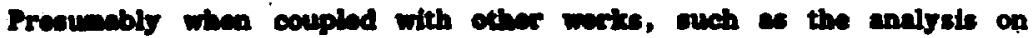
Ealt Bbok II, the ente will belp provide a syetematic scount of brine drretion phesconen.

The results is Appendices I and II do, however, eucgest that the topect of brine algration on storege of hat beariac westes in salt nay be nin because in these studive, the difcrwees in water content een

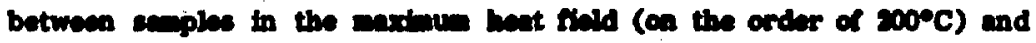
unheated expiles are enn. In other words, beating the selt in this configuration had only a enn inpet on the prepartes which were ancured.

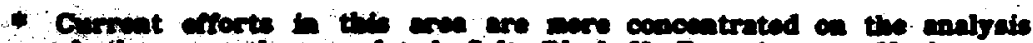

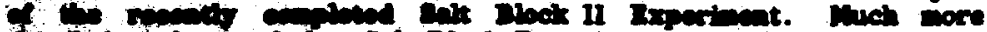

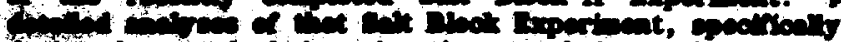

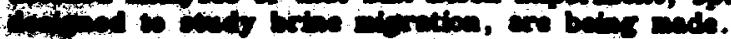




\section{Exrom vil

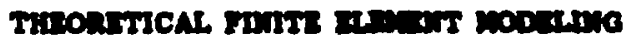

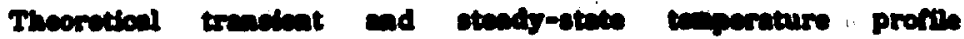

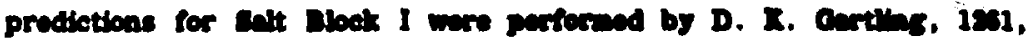

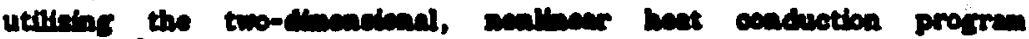

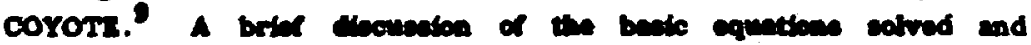

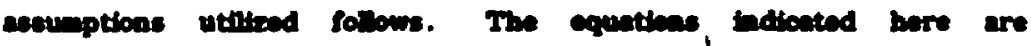

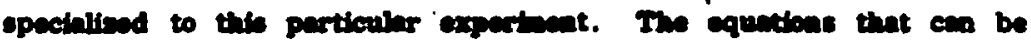

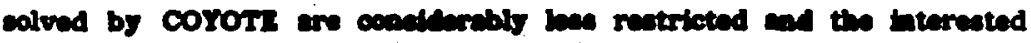

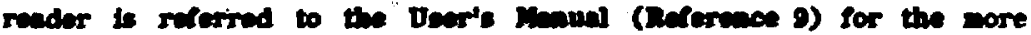
senoral anieotrople hent treafer equations that are within the capebility of COYOTI. Hote that only the theorvical eppects of the ceneral fiold equatione, boundary velese, and aunerieal procodure are presented in

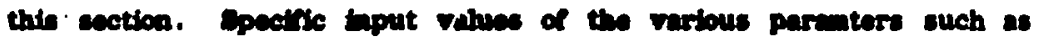
thermal cosductutities are drocuesed and premented is the following ecetion, "Lepertantal-Theocutionl Corralations."

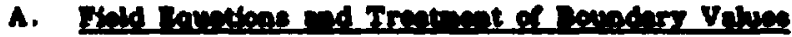

The Calt Block I tranciont and steady otate thernal resposse is

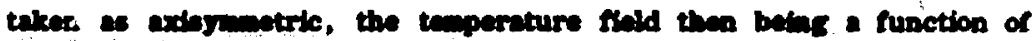
the redial coordinate, $r$, and the axdal coordinate, $z$, at a stven thes, t. 1.e.,

$$
\begin{aligned}
I=T(x, 2 ; t) & 0 \leq x \leq R \\
& 0 \leq x \leq x_{0} \\
& t \geq 0
\end{aligned}
$$

where

$$
\begin{aligned}
& T=\text { tempereture thed, }
\end{aligned}
$$

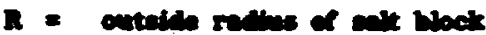




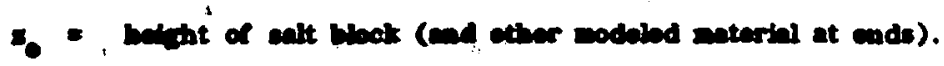

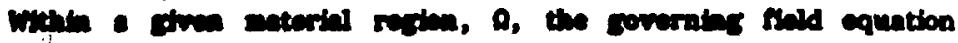

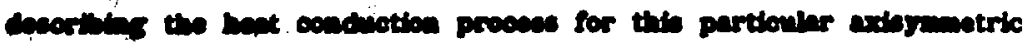

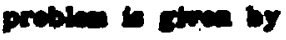

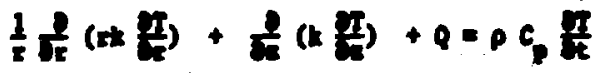

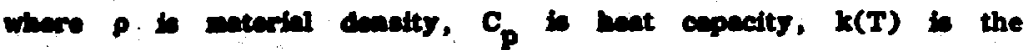

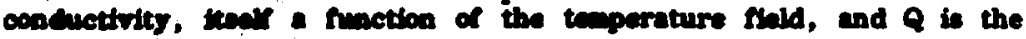

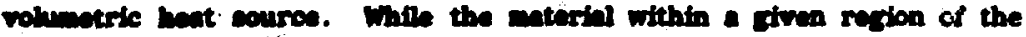

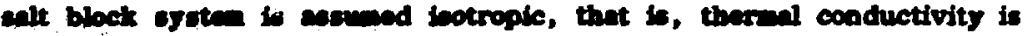
firection ivdependent, the thereal conducthity is still a function of the

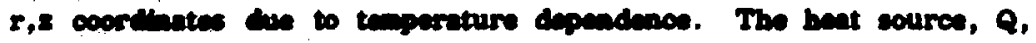
is a fuaction of the in inarid.

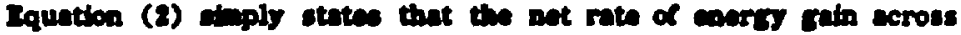

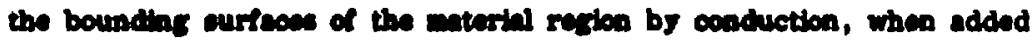

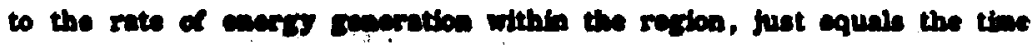

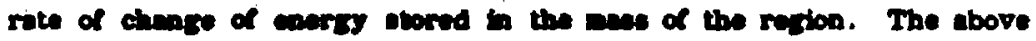
equation if of the parbolic fondy when thernal trandiats are present

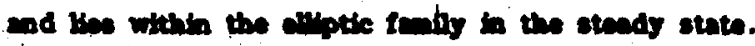

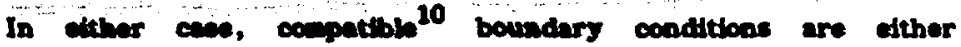
Dirichlet, for which the vine of the temperature tealf is prescribed

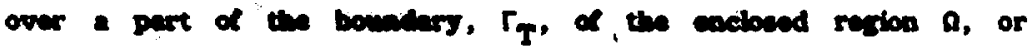

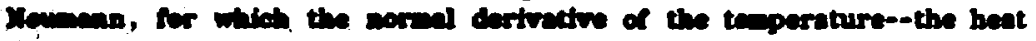

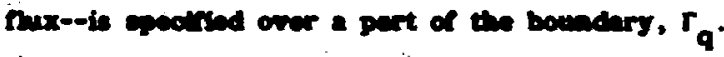

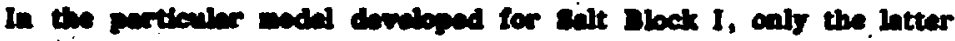

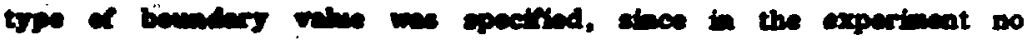

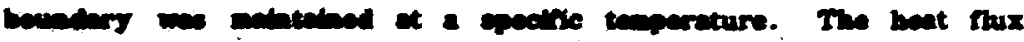

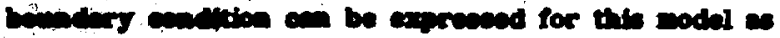

$$
4+k \frac{\pi}{4}+\varphi_{c}+4=0 \cos
$$




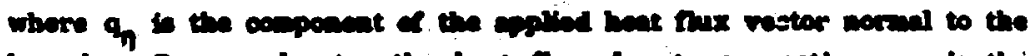

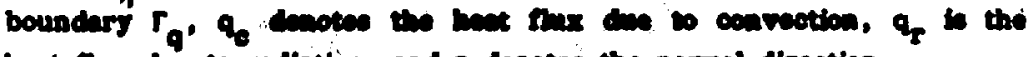

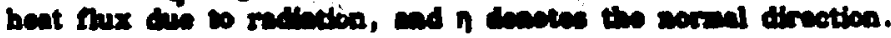

Theas convective and reciattive hat thuxes are strea by

$$
\begin{aligned}
& q_{c}=h_{c}\left(I_{b}-T_{c o b}\right) \\
& q_{2}=h_{r}\left(r_{s}-r_{e n s}\right),
\end{aligned}
$$

where $h_{c}$ and $h_{r}$ are convictive and radiative heat tranefor coefficients and $T_{f}$ and $T_{\text {mb }}$ are enrfece temperature ad mbient afr temperature, respectivaly. $h_{c}$ and $h_{r}$ are detecrined es follows for the theorntical calloulations parterned on sait sbokk I.

\section{B. Conrective Hat Tranter Complatant}

Consider the outalde hateral surface of the walt block expersment. For a vertionl orlader which conetant surfece temperature, the

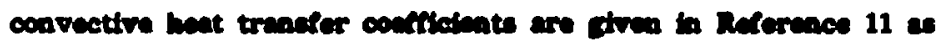

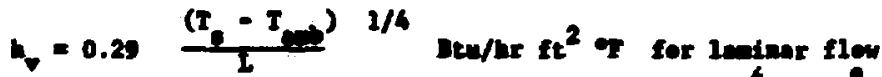

$$
\begin{aligned}
& \left(e=-10^{4} \text { to } 10^{9}\right)
\end{aligned}
$$

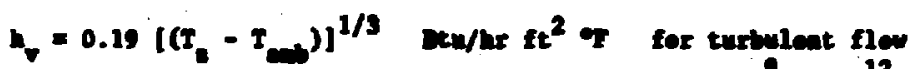

$$
\begin{aligned}
& \left(\mathrm{Cr}=10^{2} \text { to } 10^{12}\right)
\end{aligned}
$$

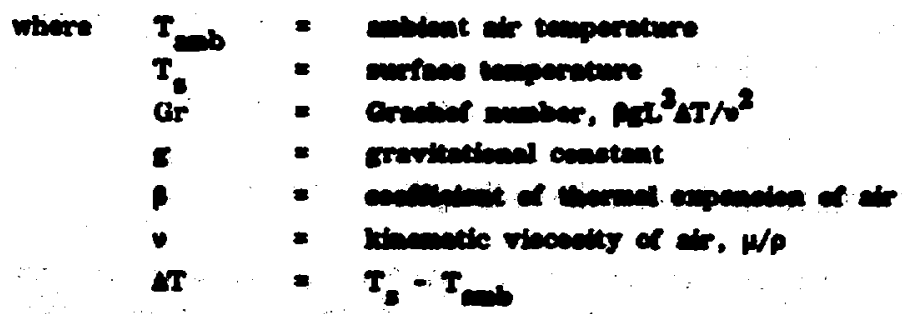




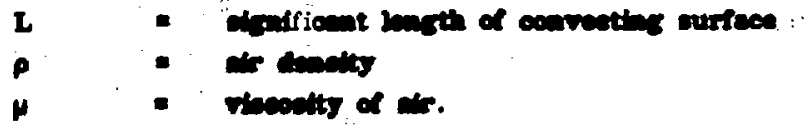

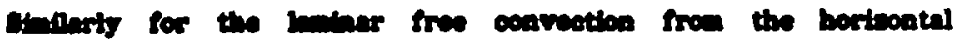

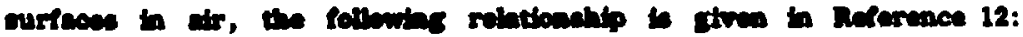

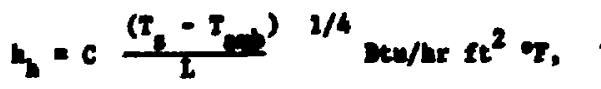

whore $C=0.27$ for upward factar bected plates and $C=0.12$ for downward fachs bated plates.

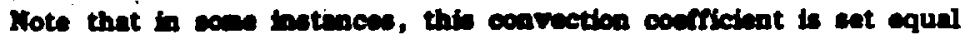
to wro in the expertmental corroletions, a decueced leter. Note that

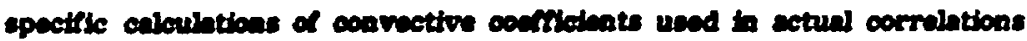
with experiments are prescaled to scetion VIIl.

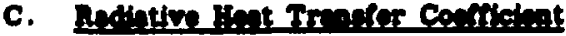

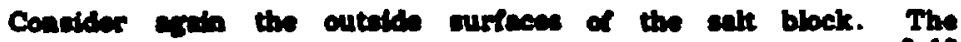

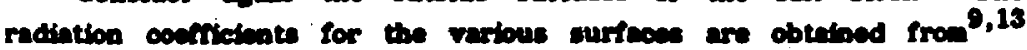

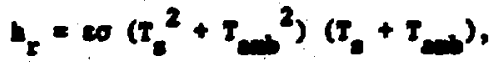

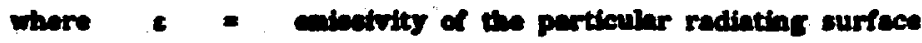

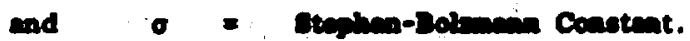

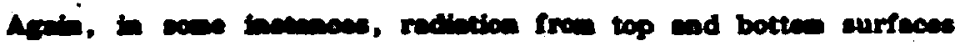

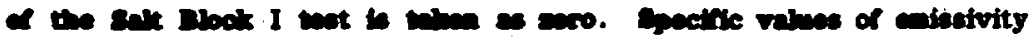

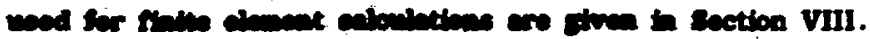

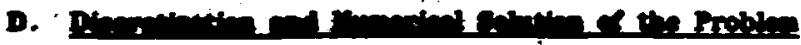

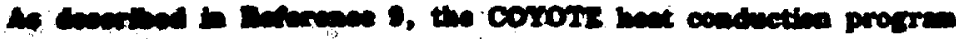

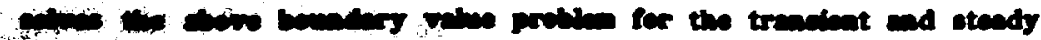


Los Alums Techniod Acsodirims, inc.

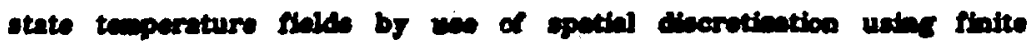

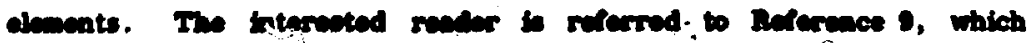

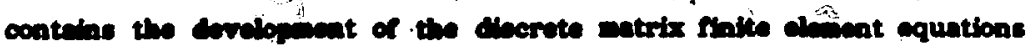
frow the continue field equations and boundary values.

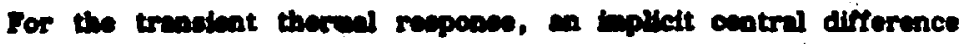

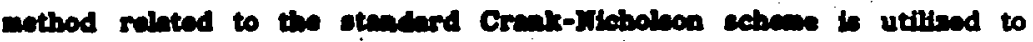

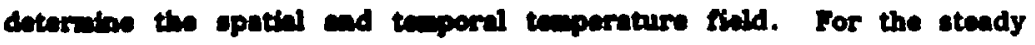
state any ais, the COYOTZ code utilizes a simple Picard iteration method. 


\section{MCTION VIII

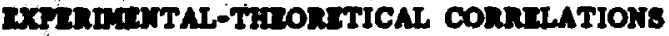

This ecetion costains comparisons of selt Bbok Test 1 recorded teaporature provies (eee section VI) with the theoreticel finite element predictions of COYOTE (en previlous section). First, the finite element nodel is ehown, followed by the material property values ueed as input to the numerical sobeme. Actull trenelent and steady state temperature profiles are then overiald with numorical predictions. This section is concluded with a list of senoral observations as well as difficulties encountered in modaling of salt Bbok 1.

\section{A. Finite Element rodel selected}

Conoiderable difficulty was tnitinlly encountered in obtaining reascablble ecrowent between caleulation and exportent for both trancient as well a steady state profibs. As a result of an extensive wet of parmeter vartations with the COYOTI proyrem, as well as a nubber of corety balance calculations, diffichacios in with initial modilins attempts, es woll es in the experimental setup, were ivolated and corrected. For eximple, redintion losees froe the vertical walls were intitilly imoced but were later, se a result of enercy balance calculations, found to be, sirnificant. Radintion boses-were subesquantly moludad in the numerical calculations. In addition, netural convection bases from top and botton surfeces wore originally isnored, but eabeepueatly found to be sicnificent. The layers of eabestos ueed in the orkinal experiment desisn were round insedequate to prevent signisicent beet lose. The experimest wes sodtried at that this to mbinky aumerieal modaline. In particular, the salt block was heavily finealated on both tep and botton by mans of two verniculite "akdrts," exfectivaly blocking the natural convection bosese fron those surfeces. Top and bottom surfeces could then be realistically nodeled es animatic. 
The final axdeymetric modal devaloped is an shown in Firure 11. Note the presence of the aix bealc material roxions modeled: sluminum plates (top and bottom), cobantos ineusintion, iso heator, the ealt, the cruched ealt, and the air opece.

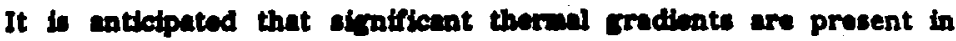
the Anlt Block I experiment. If exaningful correlations with numerical calculations are to be performed, it is eseeptial that experimental recording points are in the same secontrical position as the locations whore tamperatures are numorkeally predicted. Bince temperature are predicted at node locations in the CoYOTe code, the modeling was done such that nodal locations matched thermocouple beations.

Table III presents a ruprecentative Iint of thermocouples renerally beated alons radial lines at various belshts in the block. (These same thermocouples will be utiliead repentally for correlations to be presented subeequently.) Firet (column 1), the remernl boight in the salt block at which the redial army of thermocouples is found is indicated, followed by thermocouple number (ewe Fifurea 6, 7, and 10). The correopoeding raw date channel number is axxt presented, followed by the cylndrical coordinates beation the potnt of interest (ese Fizure 11). Then the corresponding element end nod number of the COYOTE numerical sodel is precented." This table forme the basis of conparieons to follow.

\section{B. Matorinl Property Velues Uced as Code Input}

\section{Salt Conductudty}

salt conducteity velues ued for mput to cOYOT are based upos direct menguramente wade on a core of talt Dlock I as shown in Irgure 3." The date polnts shown in Table IV were utilised to curve fit the data.

Both siment and ancociated nod nunber are nended. COYOTI does not utilies a dobal node nimberthe sjater.

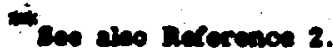



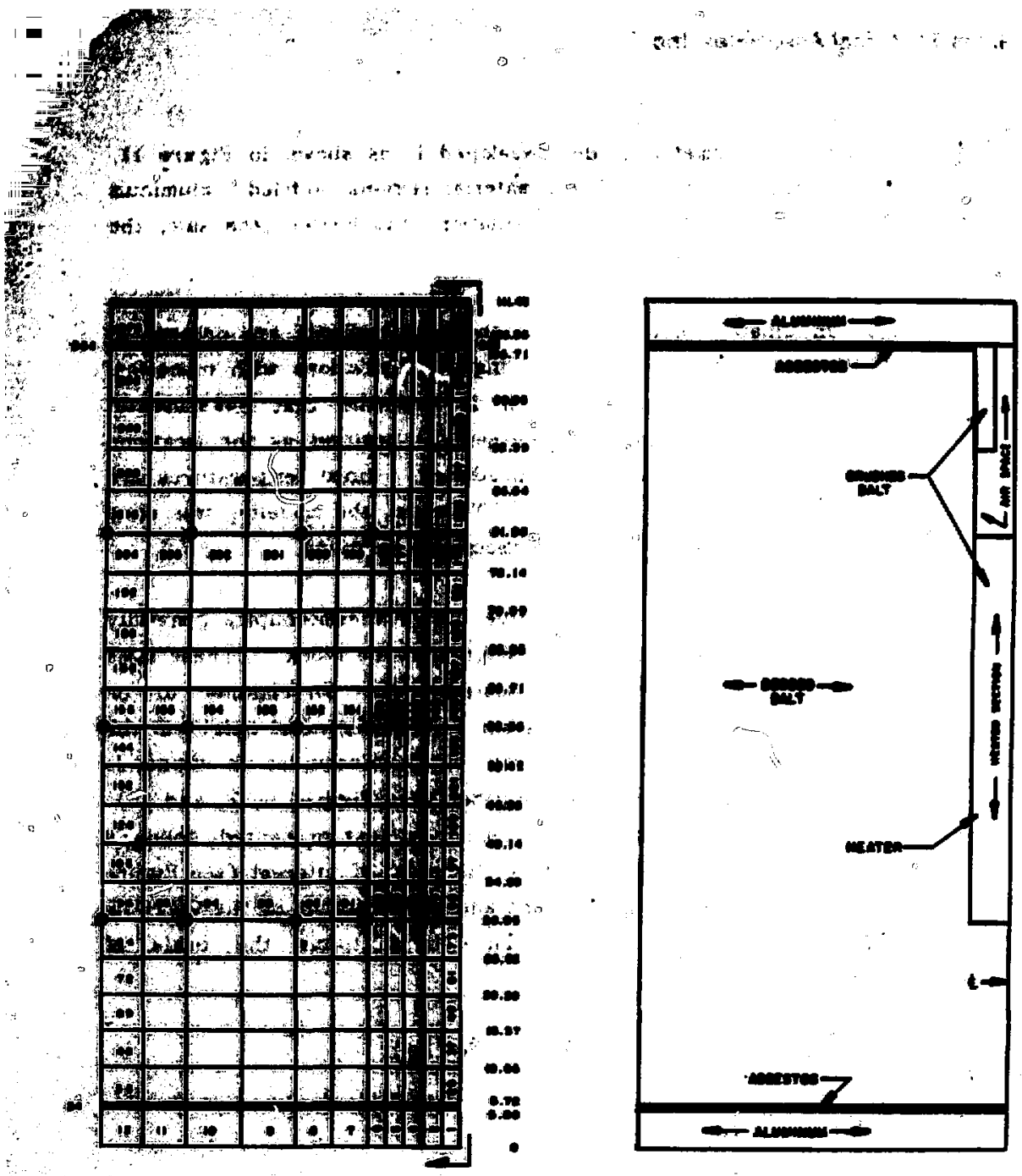

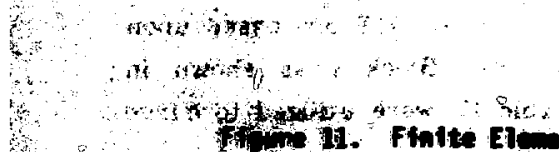

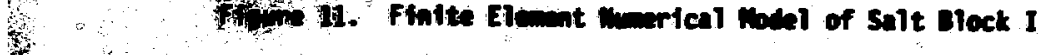

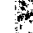

thing

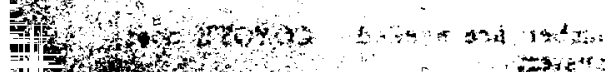




\section{TANS III}

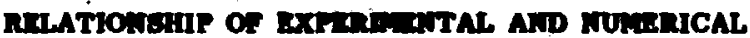

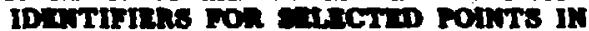
SALT BLock 1

\begin{tabular}{|c|c|c|c|c|c|c|c|}
\hline 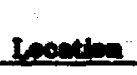 & $\begin{array}{c}\text { Therinocomple } \\
\text { No. }\end{array}$ & $\begin{array}{l}\text { Chenend } \\
\text { Ho. }\end{array}$ & B-Coend & 2-Coond & De.: & & \\
\hline of Reater & $\begin{array}{l}1 \\
20 \\
15 \\
10\end{array}$ & $\begin{array}{l}\text { ces } \\
\text { ons } \\
\text { oxs } \\
\text { ons } \\
\text { ons }\end{array}$ & 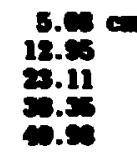 & & $\begin{array}{r}\mathbf{1 1 8} \\
151 \\
158 \\
15 \\
15\end{array}$ & & $\begin{array}{l}1 \\
1 \\
1 \\
1 \\
2\end{array}$ \\
\hline Teper & $\begin{array}{l}23 \\
19 \\
13 \\
9\end{array}$ & $\begin{array}{l}021 \\
028 \\
017 \\
013\end{array}$ & $\begin{array}{l}12.15 \\
23.11 \\
3.25 \\
5.5\end{array}$ & $\begin{array}{l}01.2 \\
01.25 \\
01.25 \\
01.25\end{array}$ & & $\begin{array}{l}\cdot \\
:\end{array}$ & $\begin{array}{l}4 \\
4 \\
4\end{array}$ \\
\hline Dotenn & $\begin{array}{l}33 \\
21 \\
16 \\
11\end{array}$ & $\begin{array}{l}000 \\
025 \\
0: 0 \\
015\end{array}$ & $\begin{array}{l}12.55 \\
23.11 \\
3.35 \\
4.51\end{array}$ & & $\begin{array}{l}\mathbf{1} \\
\frac{3}{3}\end{array}$ & & $\begin{array}{l}1 \\
1 \\
1 \\
2\end{array}$ \\
\hline Top & 8 & $\begin{array}{c}\cos \\
003\end{array}$ & 23.11 & $\begin{array}{l}111.48 \\
111.45\end{array}$ & $2 \pi$ & & 3 \\
\hline
\end{tabular}




\section{Trmant}

20

400

45

800

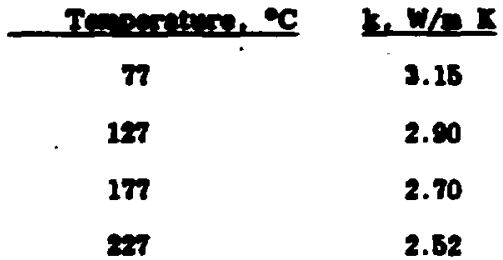

- However, see subsection I of this esction for subecquently obtained conductivity velues.

The date ware rit to a polynowial of the fors

$$
k=\omega_{1}+a_{2} T+a_{3} T^{2}+u_{4} T^{3} \text {, }
$$

were

$$
\begin{aligned}
& \bullet_{1}=3.702 \mathrm{w} / \mathrm{ax} \\
& v_{2}=-0.00037 \mathrm{w} / \mathrm{n} x^{2} \\
& { }_{3}=0.252 \times 10^{-4} \mathrm{w} / \mathrm{m} \mathrm{x}^{3} \text {. } \\
& 44=-0.4 \times 10^{-7} \mathrm{w} / \mathrm{a} x^{4} \text {. }
\end{aligned}
$$

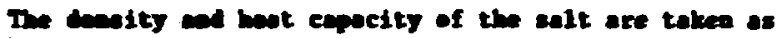

$$
\begin{aligned}
& p=135 \mathrm{~m} / \mathrm{ft} \mathrm{t}^{3}=2.16 \mathrm{~g} / \mathrm{co}^{3}
\end{aligned}
$$

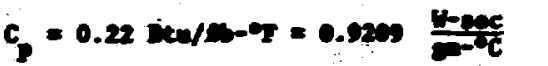




\section{2. $\max$}

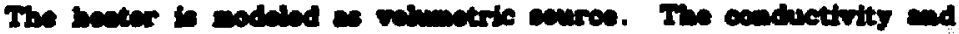

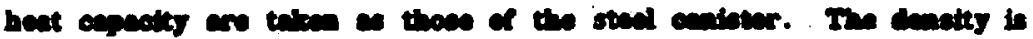

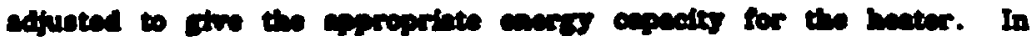

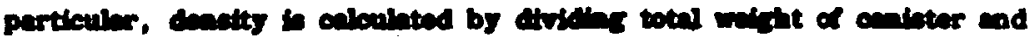

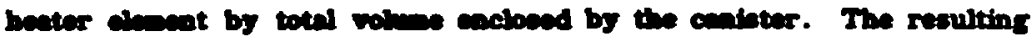
therenal prepention exe ce salows:

$$
\begin{aligned}
& \rho=3.15-2 / \mathrm{cm}^{3}
\end{aligned}
$$

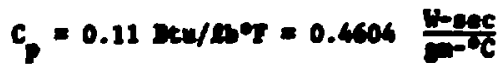

$$
\begin{aligned}
& k=26 \mathrm{Ncw} / \mathrm{hr}-\mathrm{ft}-9 \mathrm{~T}=0.46 \mathrm{H} \mathrm{\textrm {cm }} / \mathrm{co} .
\end{aligned}
$$

\section{Alropace}

The atrepece sbove the beater is ansued to have the seme propertien os the mater:

$$
\begin{aligned}
& p=3.19 \Omega / c^{3} \quad \text {, } \\
& c_{p}=0.4048-000 / 00-0 \\
& k=0.4458 \mathrm{w} / 00 \mathrm{c} \text {. }
\end{aligned}
$$

\section{Conched ent}

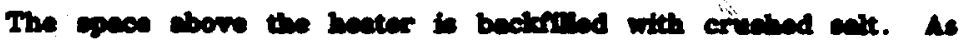

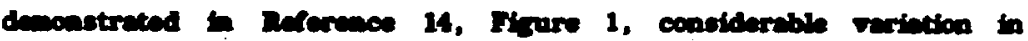

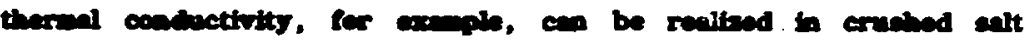

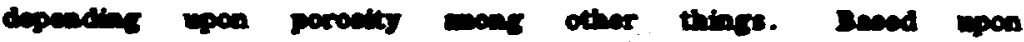

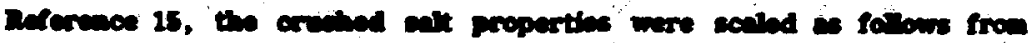

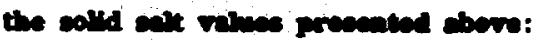

$$
p=72.5 \% p_{\text {eolld }}=1.565 \mathrm{n}^{2} \mathrm{co}^{3}
$$




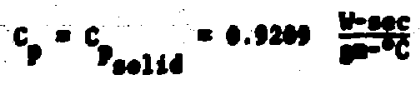

$k=7.10 \% k_{\text {enol1d }}$.

b. Anentes

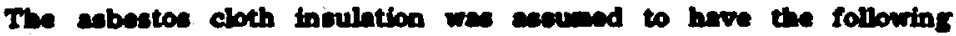
properties:

$$
\begin{aligned}
& \rho=36 \mathrm{mad} / \mathrm{ft}^{3}=0.576 \mathrm{gm} / \mathrm{cm}^{3}
\end{aligned}
$$

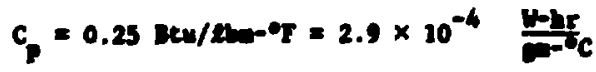

$$
\begin{aligned}
& k=0.05 \text { tew/kr-ft-0. }=1.55 \times 10^{-3} \mathrm{w} / 000-0 \mathrm{C} .
\end{aligned}
$$

\section{Alminum}

The top and botton chunthun plates were cosumed to have the followiac properties:

$$
\begin{aligned}
& p=1.60 \mathrm{mat} / \mathrm{ft}^{3}=2.71 \mathrm{~m} / \mathrm{cos}^{3}
\end{aligned}
$$

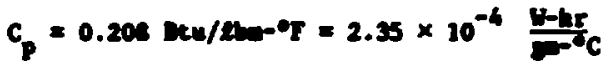

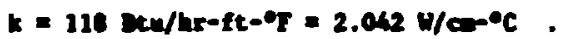

\section{c. Steadr stove Comparionse}

1. $Q=1,000 \mathrm{w}$

The firet one of suberical-compariecons reportod here correepond to

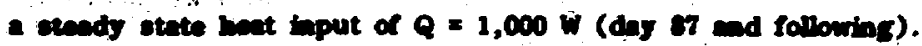




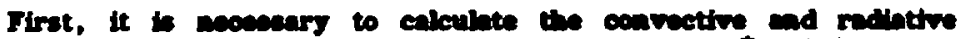

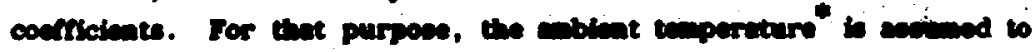

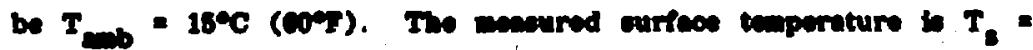

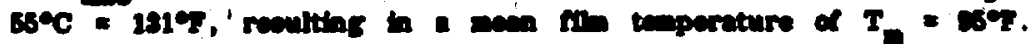

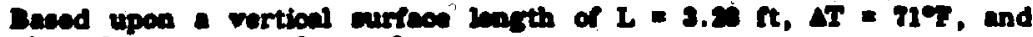

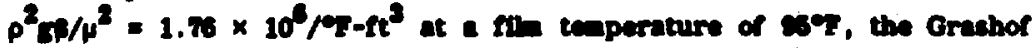
number is

$$
\text { Or }=4.4 \times 10^{\circ}
$$

which is fust over the turbulent 1 int. stace nost 0 the surfece will be subjected to lentriar flow, the lninar corrintion, Iq. (5), is used. The resulting convective cocticient is

$$
h_{c}=3.85 \mathrm{~W} / \mathrm{m}^{2}-{ }^{\circ} \mathrm{C}
$$

The rediative conflicient is deternined from $\mathrm{Zq}$. (7) usine $c=0.9$ (for parated surfeos at a tempernture less than $200 \%$ ) and $\sigma=0.1713 x$ $10^{-1}$ Btu/ar-ft ${ }^{2}-\mathrm{n}^{4}$. The colticient becomes

$$
h_{r}=6.026 w / 0^{2}-\oplus c
$$
$w / m^{2}-9$.

The combined hat transfer conficiont is then $h=h_{c}+h_{r}=9.565$

As described in section VI, on Apri 7 (day o7), 1977, verniculite insulation we placed sbout the top and botton of the salt block and fixtures and power wes reduead to 1,000 $\mathrm{W}$ and hald at this level until Aprl 14. As mentioned eartior, the rmecen for modification of the experimental frxture we for sinpilication of the numerien modal. Thus nore then apple the we avaluble for the temperature procile to reach steady state.

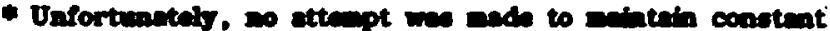

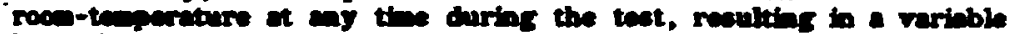
beat ink terecretare.
}

moteady state we pormany recolved overnight. 


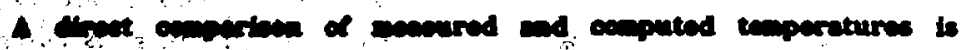

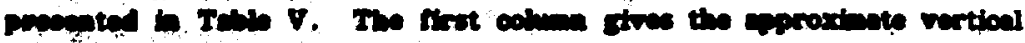

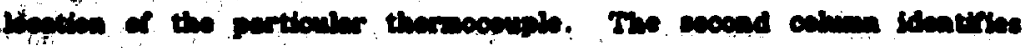

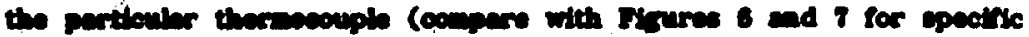
boption). In sext colmens is the recorded enperabure while the

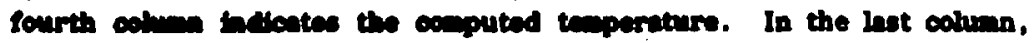
the peroent error is indionted. With fow excoptione, exrecenent is quite cood cossibering the complexity of the model. The larteot diecrepancy benerally was at the outelde wall.

The steady state temperature profie is plotted in Figure 12 for two vertical levels in the alt block: at mibuintht of the batter and at the botton of the hater. The solid and broken lanes identify the computed protiles at the two bocations, whereas the etreular and equare points desote expertmeatal thermocouple dath. The nidheight radial

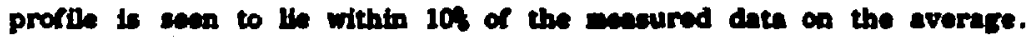




\section{TAYIV}

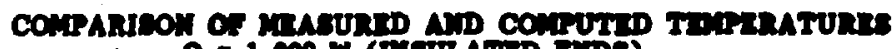

$Q=1,000 \times$ (IIDULATD ImD)

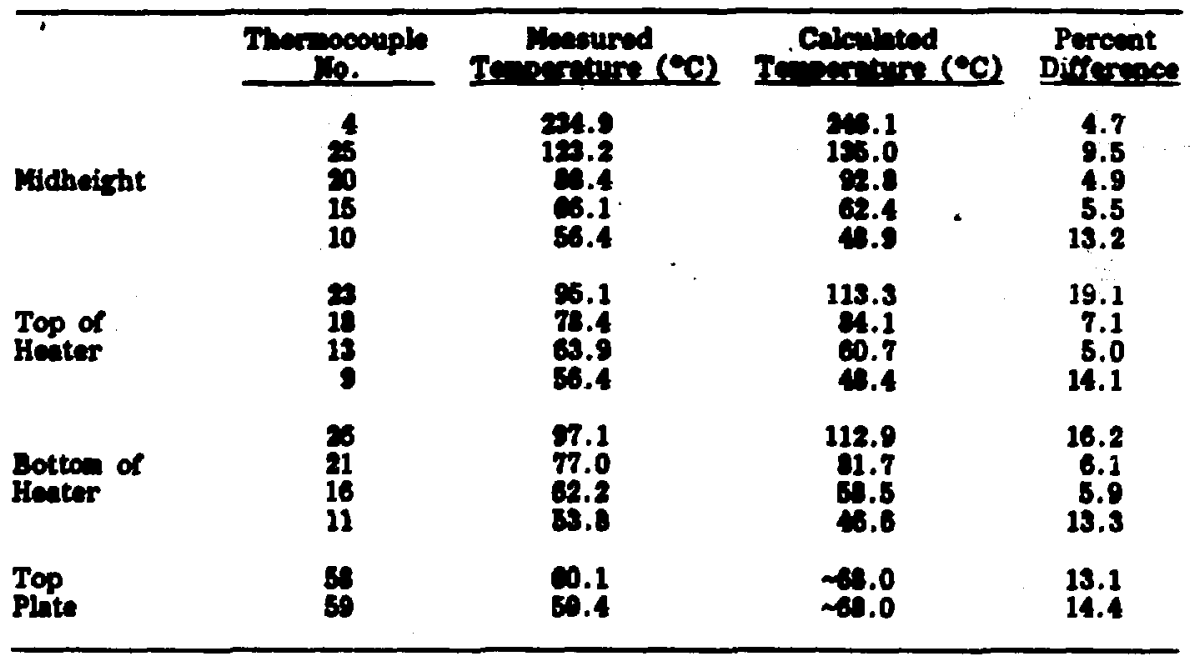




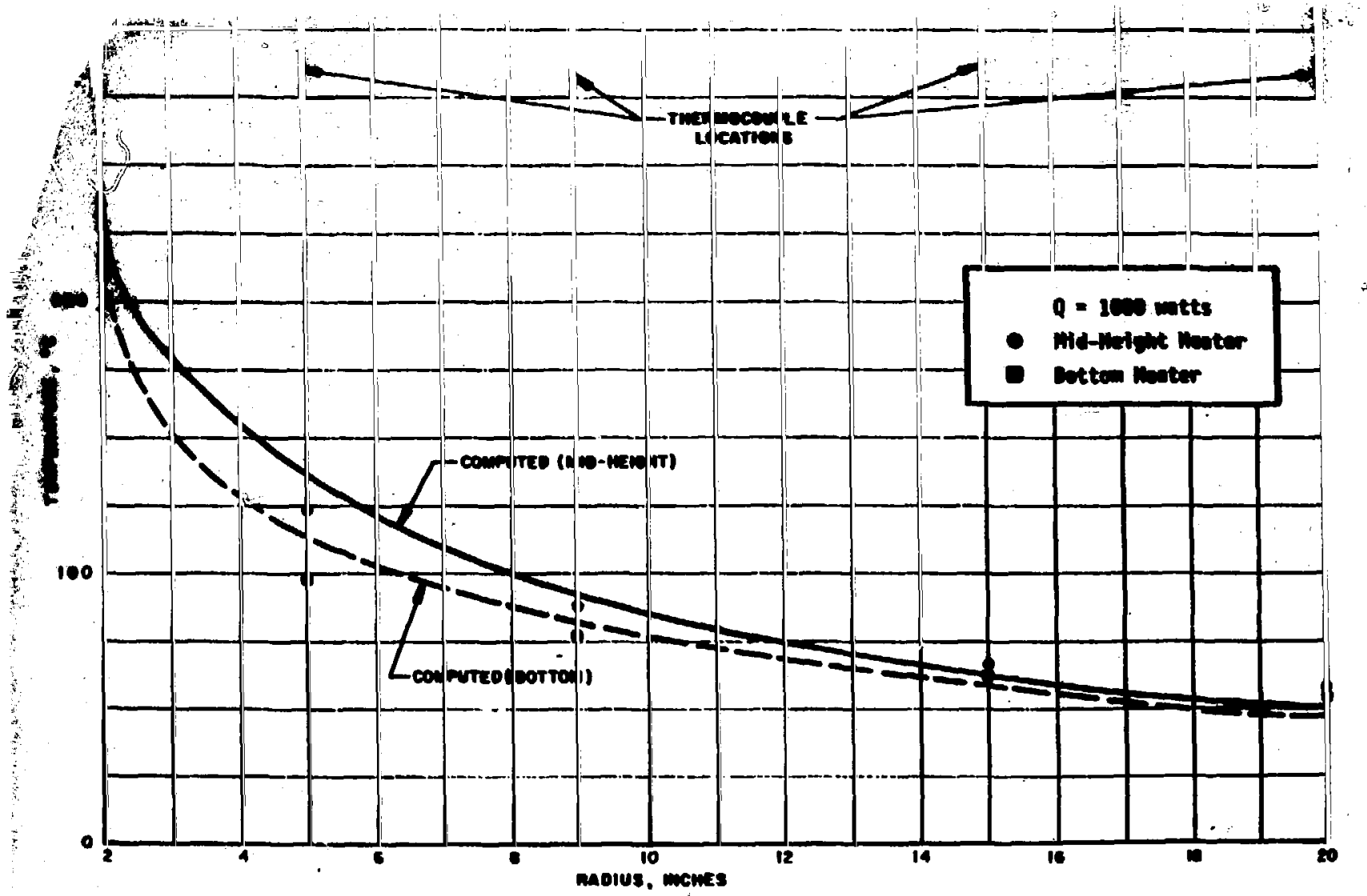

Finure 12. Steady State Temperature Profile Comparison: $Q=1000$ watts. 


\section{2. $Q=\operatorname{sen} w$}

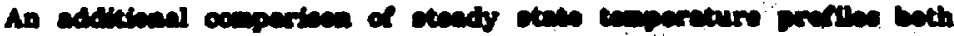

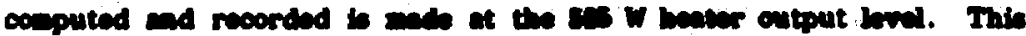

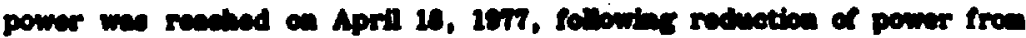

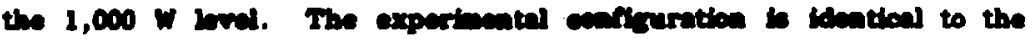

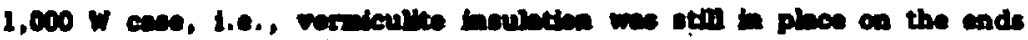
of the sylinder:

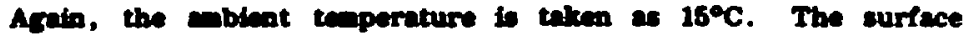
tempernture is of course bwer, $I_{s}=42.3^{\circ} \mathrm{C}$. Based upos laninar flow, the convection conficiant (Iq. 6) is enloulated as.

$$
b_{c}=3.220 \mathrm{w} / \mathrm{m}^{2}-{ }^{\circ} \mathrm{c}
$$

The radintion conficiont to egain found ustag Iq. (7) to be

$$
h_{r}=6.642 w / m^{2}-0 c
$$

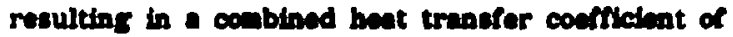

$$
h=0.096 / m^{2}-\omega^{\circ}
$$

A comparison at this bower power boul bs shown to Table VI uning the wene format as Table $v$. Further, theoration and experientent profibs

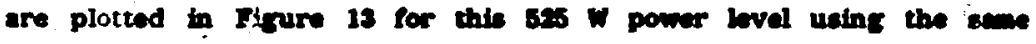
format as Fixure 12. Inealts ware os food or better then the 1,000-watt conpurioon."

* Besed upon comperinon of Frares 12 and 13 . Hote that perrentey

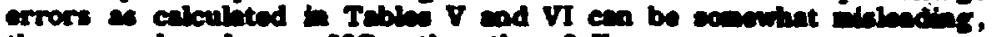
they wore beesd upen orc rether then $0 \mathrm{I}$. 
This vi

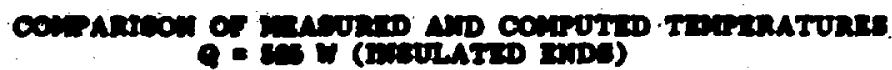

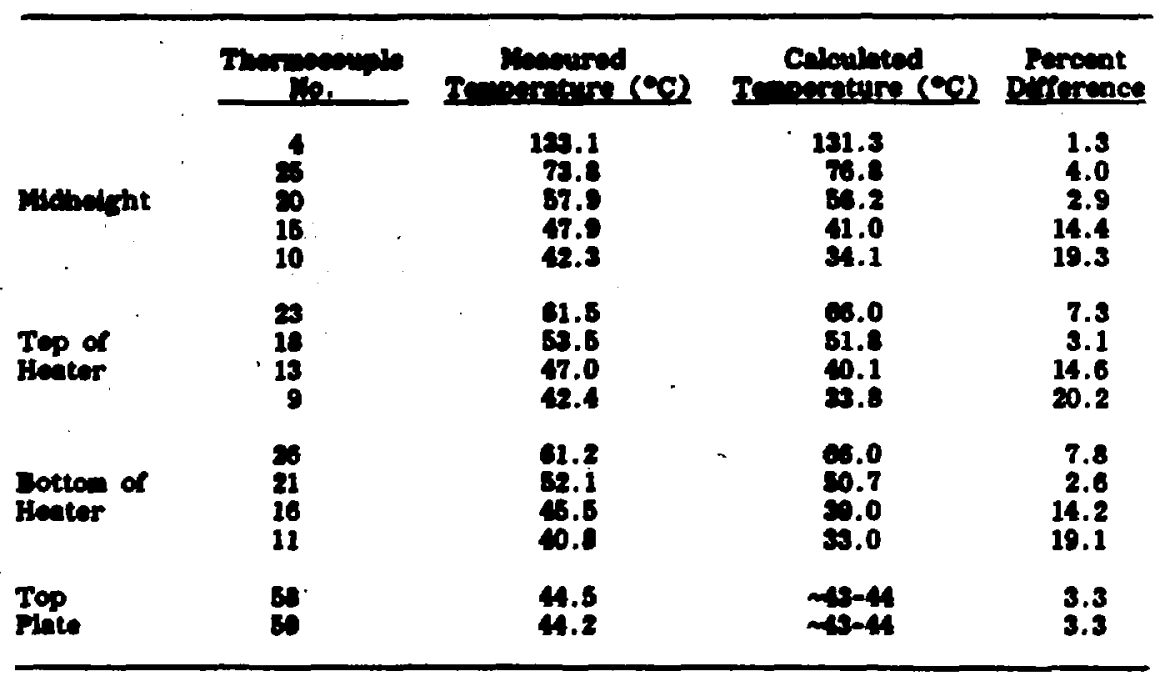


Technion Anosolenes, inc.

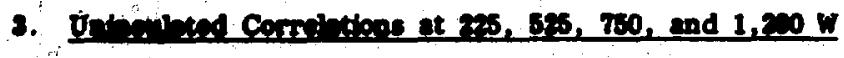

Baced upon the suocese of the experinental-sunericul stoady state

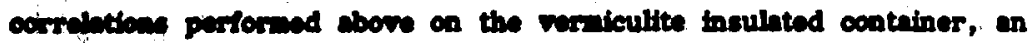
attangt we then made to so beck to the date senerated during the aritiar ays of the Ealt block I teat and devilop further correlations wh sumerten predictions.

Since the eariser date were senerated without adequate insulation on the ends, It was neceseary to account for both convective and rediative bieses at these beations. In the following four "unineulated" correlations (parforned at "steady itate" power bevels of 225, 525, 750, and $1220 \mathrm{~W}$, respectively) the rediation losese wore handled in a nethod anuloyous to those described above, except that an missivity of $c=0.3$ was used for top and bottom murfeces ( $2=0.8$ still being used for the lateral vertical surfece of the cylinder). In addition, convection irom lower and upper enrteces is tachuded using the equatione in Ecetion VII B. Caleulatione of the respective radiation and convection conficients is etraichtforward and analopous to calculntions in the inculated correlation esctibas above. The calculations are onitted here for brevtly.

The firet comparicon (225 W) is presented in Table VII. Arrengemate of this table is ainilar to Tables $V$ and VI, except that a Hitth sore deted is included. In particular, the renge in recorded temperatures for the stren thernocouple is indicated. since the $Q=$ 275 w was bed "ionetent" for day 4 throurch day 6 , the tenperature

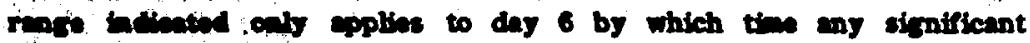

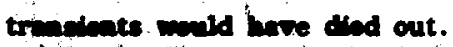

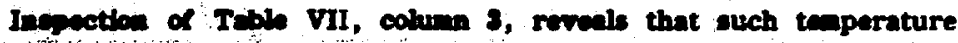

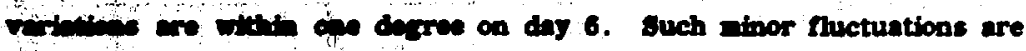

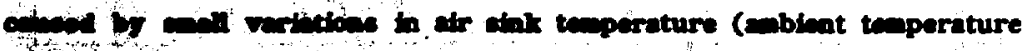

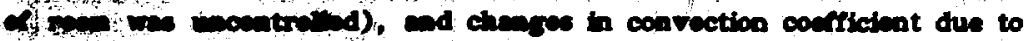

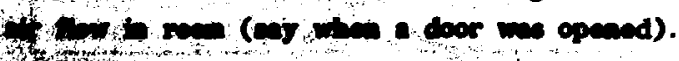


TABLE VII

COMPARISON OF MEASURED AND COMPUTEIS TEMPERATURES: $Q=225 W$ (UNINSULATED)

\begin{tabular}{|c|c|c|c|c|c|c|c|}
\hline $\begin{array}{l}\text { Gemaral } \\
\text { Locution }\end{array}$ & & $\begin{array}{c}\text { Therrocouple } \\
\text { No. }\end{array}$ & $\begin{array}{l}\text { Teop. Range } \\
\text { peneured oc }\end{array}$ & $\begin{array}{l}\text { Mean Teop. } \\
\text { Eeasured }{ }^{\circ} \mathrm{C}\end{array}$ & $\begin{array}{l}\text { Teaperature } \\
\text { Cooputed o }\end{array}$ & $\begin{array}{c}\text { Abeolute } \\
\text { Durference }{ }^{\circ} \mathrm{C}\end{array}$ & $\begin{array}{c}\text { Perwent } \\
\text { Difrerence }\end{array}$ \\
\hline Menceryt of & $\therefore$ & $\begin{array}{l}4 \\
25 \\
15 \\
10\end{array}$ & $\begin{array}{l}67.3-67.9 \\
39.7-40.1 \\
30.3-30.5 \\
20.2-28.6\end{array}$ & $\begin{array}{l}67.6 \\
39.9 \\
30.4 \\
20.4\end{array}$ & $\begin{array}{l}63.9 \\
40.5 \\
26.5 \\
23.9\end{array}$ & $\begin{array}{l}3.7 \\
0.6 \\
3.9 \\
4.5\end{array}$ & $\begin{array}{r}5.5 \\
1.5 \\
12.8 \\
15.8\end{array}$ \\
\hline Top of & & $\begin{array}{r}23 \\
18 \\
13 \\
9\end{array}$ & $\begin{array}{r}35.9-36.3 \\
32.3-32.6 \\
29.9-30.2 \\
20.1-20.5\end{array}$ & $\begin{array}{l}36.1 \\
.32 .4 \\
30.0 \\
28.3\end{array}$ & $\begin{array}{l}35.5 \\
29.9 \\
25.5 \\
23.2\end{array}$ & $\begin{array}{l}0.6 \\
2.5 \\
4.5 \\
5.1\end{array}$ & $\begin{array}{r}1.7 \\
7.7 \\
15.0 \\
18.0\end{array}$ \\
\hline $\begin{array}{l}\text { Bottion of } \\
\text { Henter }\end{array}$ & & $\begin{array}{l}20 \\
21 \\
16 \\
11\end{array}$ & $\begin{array}{l}34.8-35.2 \\
31.4-31.8 \\
28.9-29.3 \\
27.4-27.8\end{array}$ & $\begin{array}{l}35.0 \\
31.6 \\
29.1 \\
27.6\end{array}$ & $\begin{array}{l}36.1 \\
30.0 \\
25.5 \\
23.2\end{array}$ & $\begin{array}{l}1.1 \\
1.6 \\
3.6 \\
4.4\end{array}$ & $\begin{array}{r}3.1 \\
5.1 \\
12.3 \\
15.9\end{array}$ \\
\hline $\begin{array}{l}\text { Top } \\
\text { PLite }\end{array}$ & & 59 & $20.8-27.3$ & 27.0 & 23.6 & $\therefore 4$ & 12.6 \\
\hline
\end{tabular}

* Beced upon average experimental reading. 


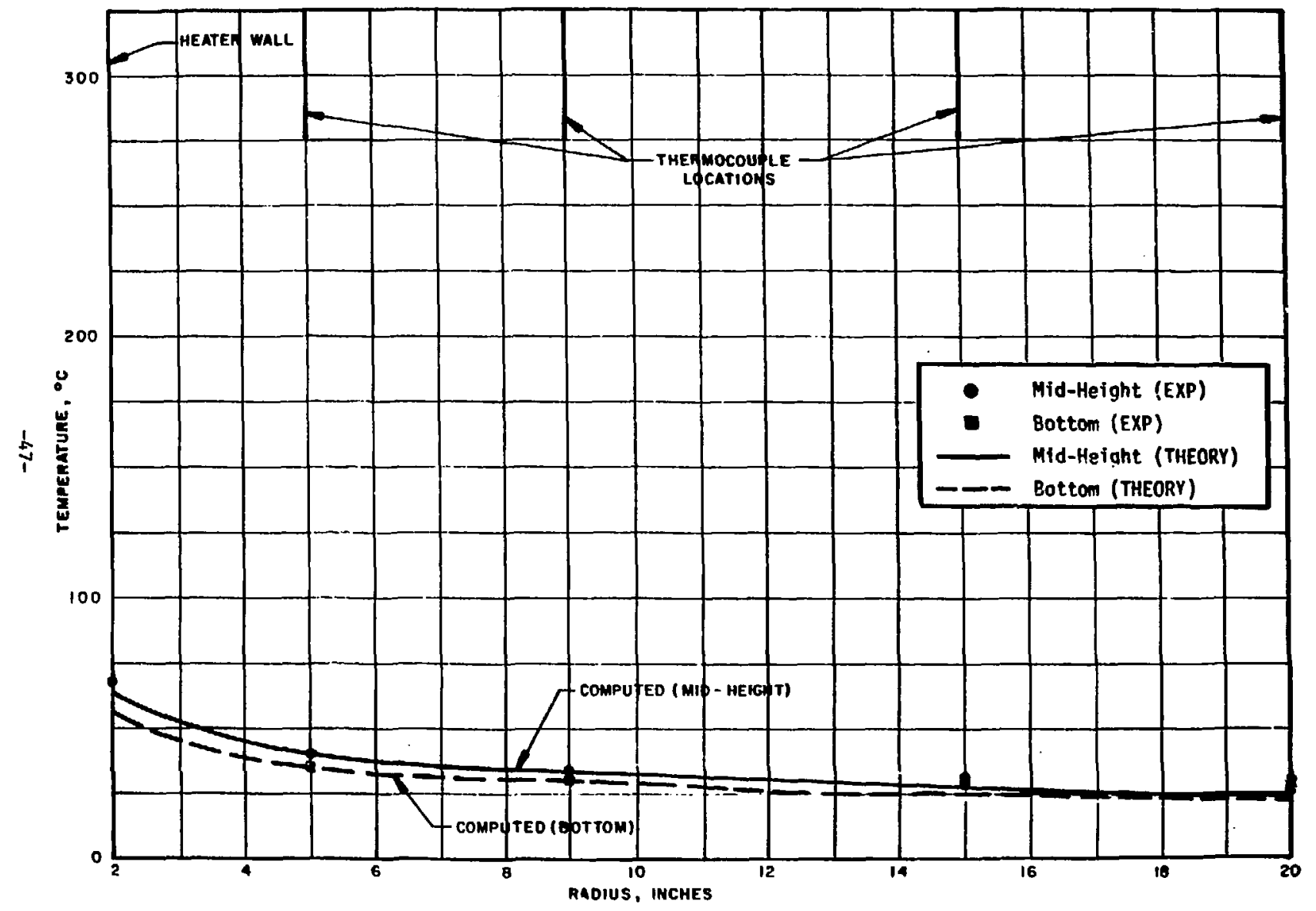

Figure 14. Steady State Temperature Profile Comparison: $0=225$ watts. 


\section{TABLE VIII}

COMPARISON OF MEASURED AND COMPUTED TEMPERATURES:

$Q=525 W$

(Day 10)

\begin{tabular}{|c|c|c|c|c|c|c|}
\hline $\begin{array}{l}\text { General } \\
\text { Location }\end{array}$ & $\begin{array}{c}\text { Thermocouple } \\
\text { No. }\end{array}$ & $\begin{array}{c}\text { Temp. Range } \\
\text { Measured }{ }^{\circ} \mathrm{C}\end{array}$ & $\begin{array}{l}\text { Mean Temp. } \\
\text { Measured }{ }^{\circ} \mathrm{C}\end{array}$ & $\begin{array}{l}\text { Temperature } \\
\text { Computed }{ }^{\circ} \mathrm{C}\end{array}$ & $\begin{array}{c}\text { Absolute } \\
\text { Difference }{ }^{\circ} \mathrm{C}\end{array}$ & $\begin{array}{c}\text { Percent } \\
\text { Difference }\end{array}$ \\
\hline $\begin{array}{l}\text { Midheight of } \\
\text { Heater }\end{array}$ & $\begin{array}{l}4 \\
25 \\
20 \\
15 \\
10\end{array}$ & $\begin{array}{c}128.1-129.4 \\
63.1-64.1 \\
48.0-48.7 \\
37.9-38.7 \\
33.9-35.0\end{array}$ & $\begin{array}{r}128.7 \\
63.6 \\
48.4 \\
38.3 \\
34.4\end{array}$ & $\begin{array}{r}127.1 \\
72.9 \\
52.9 \\
38.7 \\
32.5\end{array}$ & $\begin{array}{l}1.6 \\
9.3 \\
4.5 \\
0.4 \\
1.9\end{array}$ & $\begin{array}{r}1.2 \\
14.6 \\
9.3 \\
1.0 \\
5.5\end{array}$ \\
\hline $\begin{array}{l}\text { Top of } \\
\text { Heater }\end{array}$ & $\begin{array}{r}23 \\
18 \\
13 \\
9\end{array}$ & $\begin{array}{l}51.2-52.1 \\
42.9-43.7 \\
36.2-37.2 \\
32.8-34.2\end{array}$ & $\begin{array}{l}51.7 \\
43.3 \\
36.7 \\
33.5\end{array}$ & $\begin{array}{l}60.4 \\
46.8 \\
36.2 \\
31.0\end{array}$ & $\begin{array}{l}8.7 \\
3.5 \\
0.5 \\
2.5\end{array}$ & $\begin{array}{r}16.8 \\
8.0 \\
1.4 \\
7.5\end{array}$ \\
\hline $\begin{array}{l}\text { Bottom of } \\
\text { Heater }\end{array}$ & $\begin{array}{l}26 \\
21 \\
16 \\
11\end{array}$ & $\begin{array}{l}51.7-52.6 \\
42.8-43.5 \\
35.9-36.7 \\
32.5-33.7\end{array}$ & $\begin{array}{l}52.2 \\
43.2 \\
36.3 \\
33.1\end{array}$ & $\begin{array}{l}61.9 \\
47.1 \\
36.2 \\
31.0\end{array}$ & $\begin{array}{l}9.7 \\
3.9 \\
0.1 \\
2.1\end{array}$ & $\begin{array}{r}18.6 \\
9.0 \\
0.3 \\
6.3\end{array}$ \\
\hline $\begin{array}{l}\text { Top } \\
\text { Plate }\end{array}$ & $\begin{array}{l}58 \\
59\end{array}$ & $\begin{array}{l}29.0-31.0 \\
29.0-30.9\end{array}$ & $\begin{array}{l}30.0 \\
30.0\end{array}$ & $\begin{array}{l}32.0 \\
31.7\end{array}$ & $\begin{array}{l}2.0 \\
1.7\end{array}$ & $\begin{array}{l}6.7 \\
5.7\end{array}$ \\
\hline
\end{tabular}




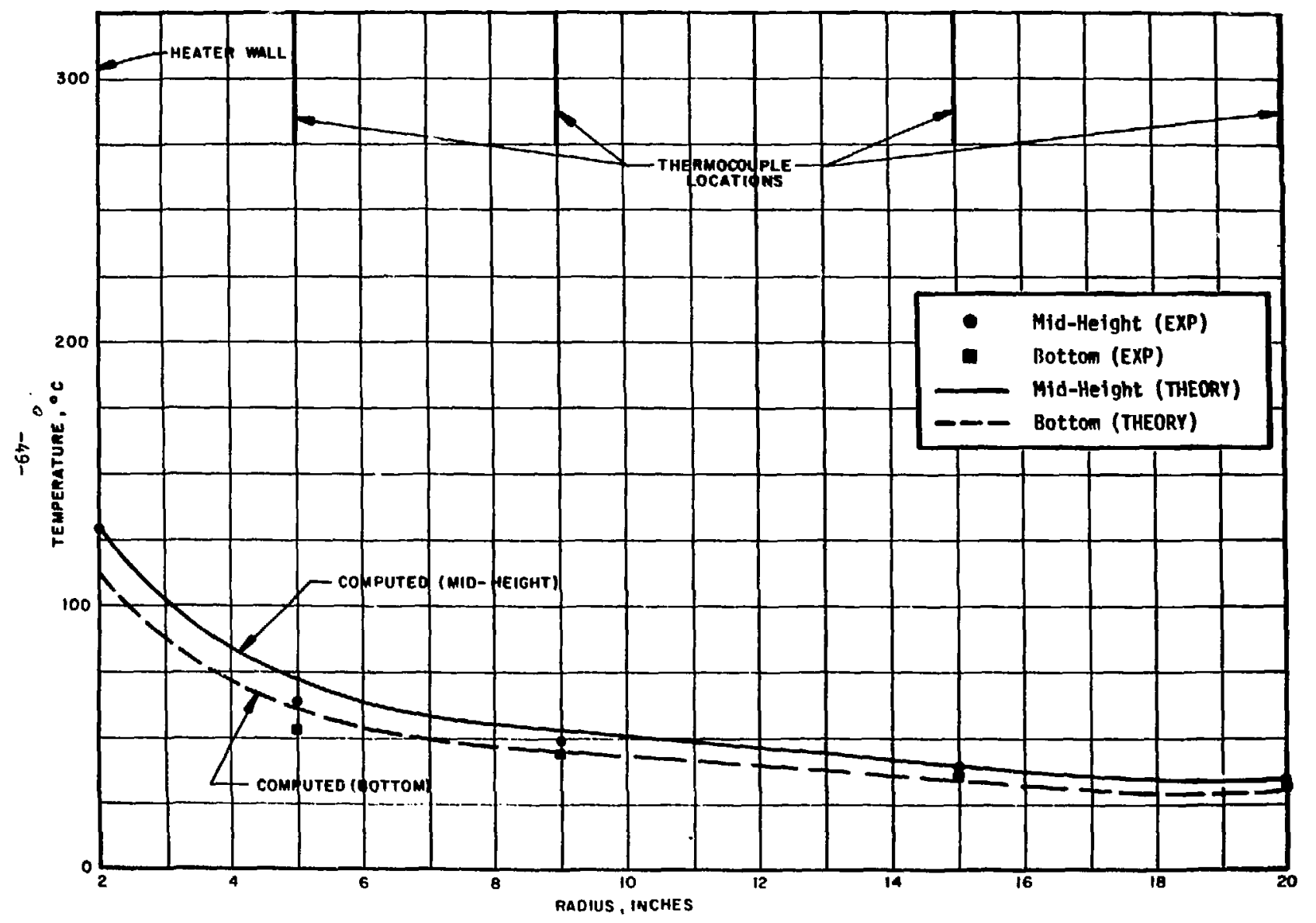

Fiqure 15. Steady State Temperature Profile Comparison: $\eta=525$ watts. 
The next comparion ts at a heater output of $750 \mathrm{~W}$, which was reached on day 22 at $0900 \mathrm{hr}$. The range in palues of recorded temperature, shown in Table $I X$, is based on maxima and minima recorded from $8 \mathrm{p.m}$. that evening through 8 a.m. the following morning, azoin in an attempt to conpare steady state readings with corresponding stendy state predictions.

As at lower power levels, predictions are somewhat low at the $r=5$ in. locations, although agreement at the heater wall as well as at the other radial positions are excellent. For visualization purposes, experimental and numerical steady state temperature profiles are plotted in Figure 16 as a function of radius at elevations corresponding to heater midheight and bottom.

The final comparizon is at maximum heater power $(1,280 \mathrm{~W})$, again still in the "uninsulated" configuration, that is, the vermiculite skirt has not yet been added to each end of the cylinder. This power level was maintained for days 46 to 48 of the test.

Both experimental as well as numerical temperature rangei and values, respectively, are presented in Table $X$. Again, to assure steady state conditions, the indicated experimental temperature ranges are based upon day 48 . As Table $X$ illustrates, correlations at the heater wall at this high power level are excellent (thermocouple No. 4), whereas those temperature values recorded at 5-in. radius (No. 25, No. 23, and No. 26) are disturbingly off as has been observed at all power levels. Correlations at other radial locations can best be described as good to excellent.

Finally, "midheight" and "bottom" profiles are as shown in Figure 17 for this $1,280 \mathrm{~W}$ situation. It is readily seen that predictions are inadequate at the 5-in. radial position, although at least satisfactory elsewhere. 


\section{TABLE IX}

COMPARISON OF MEASURED AND COMPUTED TEMPERATURES

$Q=750 W$ (UNINSULATED)

\begin{tabular}{|c|c|c|c|c|c|c|}
\hline $\begin{array}{l}\text { General } \\
\text { Location }\end{array}$ & $\begin{array}{c}\text { Thermocouple } \\
\text { No. }\end{array}$ & $\begin{array}{c}\text { Temp. Range } \\
\text { Measured }{ }^{\circ} \mathrm{C}\end{array}$ & $\begin{array}{l}\text { Mean Temp. } \\
\text { Measured }{ }^{\circ} \mathbf{C}\end{array}$ & $\begin{array}{l}\text { Temperature } \\
\text { Computed }{ }^{\circ} \mathrm{C}\end{array}$ & $\begin{array}{c}\text { Absolute } \\
\text { Difference }{ }^{\circ} \mathrm{C}\end{array}$ & $\begin{array}{c}\text { Percent } \\
\text { Difference }\end{array}$ \\
\hline $\begin{array}{l}\text { Midheight of } \\
\text { Heater }\end{array}$ & $\begin{array}{l}4 \\
25 \\
20 \\
15 \\
10\end{array}$ & $\begin{array}{c}181.2-183.6 \\
87.7-88.8 \\
64.0-64.6 \\
48.7-49.4 \\
42.9-43.7\end{array}$ & $\begin{array}{r}182.4 \\
88.3 \\
64.3 \\
49.0 \\
43.3\end{array}$ & $\begin{array}{r}177.6 \\
97.6 \\
68.1 \\
47.3 \\
38.3\end{array}$ & $\begin{array}{l}4.8 \\
9.3 \\
3.8 \\
1.7 \\
5.0\end{array}$ & $\begin{array}{r}2.6 \\
10.5 \\
5.9 \\
3.4 \\
11.5\end{array}$ \\
\hline $\begin{array}{l}\text { Top of } \\
\text { Heater }\end{array}$ & $\begin{array}{r}23 \\
18 \\
13 \\
9\end{array}$ & $\begin{array}{l}67.8-68.8 \\
55.9-56.5 \\
45.9-46.7 \\
41.2-42.1\end{array}$ & $\begin{array}{l}68.3 \\
56.2 \\
46.3 \\
41.6\end{array}$ & $\begin{array}{l}79.4 \\
59.2 \\
43.8 \\
36.3\end{array}$ & $\begin{array}{r}11.1 \\
3.0 \\
2.5 \\
5.3\end{array}$ & $\begin{array}{r}16.3 \\
5.3 \\
5.4 \\
12.7\end{array}$ \\
\hline $\begin{array}{l}\text { Bottom of } \\
\text { Heater }\end{array}$ & $\begin{array}{l}26 \\
21 \\
16 \\
11\end{array}$ & $\begin{array}{l}70.7-71.4 \\
56.7-57.2 \\
46.1-46.6 \\
41.0-42.0\end{array}$ & $\begin{array}{l}71.1 \\
57.0 \\
46.3 \\
41.5\end{array}$ & $\begin{array}{l}81.5 \\
59.6 \\
43.8 \\
36.2\end{array}$ & $\begin{array}{r}10.4 \\
2.6 \\
2.5 \\
5.3\end{array}$ & $\begin{array}{r}14.6 \\
4.6 \\
5.4 \\
12.8\end{array}$ \\
\hline $\begin{array}{l}\text { Top } \\
\text { Plate }\end{array}$ & $\begin{array}{l}58 \\
59\end{array}$ & $\begin{array}{l}35.8-37.3 \\
35.7-37.2\end{array}$ & $\begin{array}{l}36.7 \\
36.5\end{array}$ & $\begin{array}{l}37.8 \\
37.3\end{array}$ & $\begin{array}{l}1.1 \\
0.8\end{array}$ & $\begin{array}{l}3.0 \\
2.2\end{array}$ \\
\hline
\end{tabular}




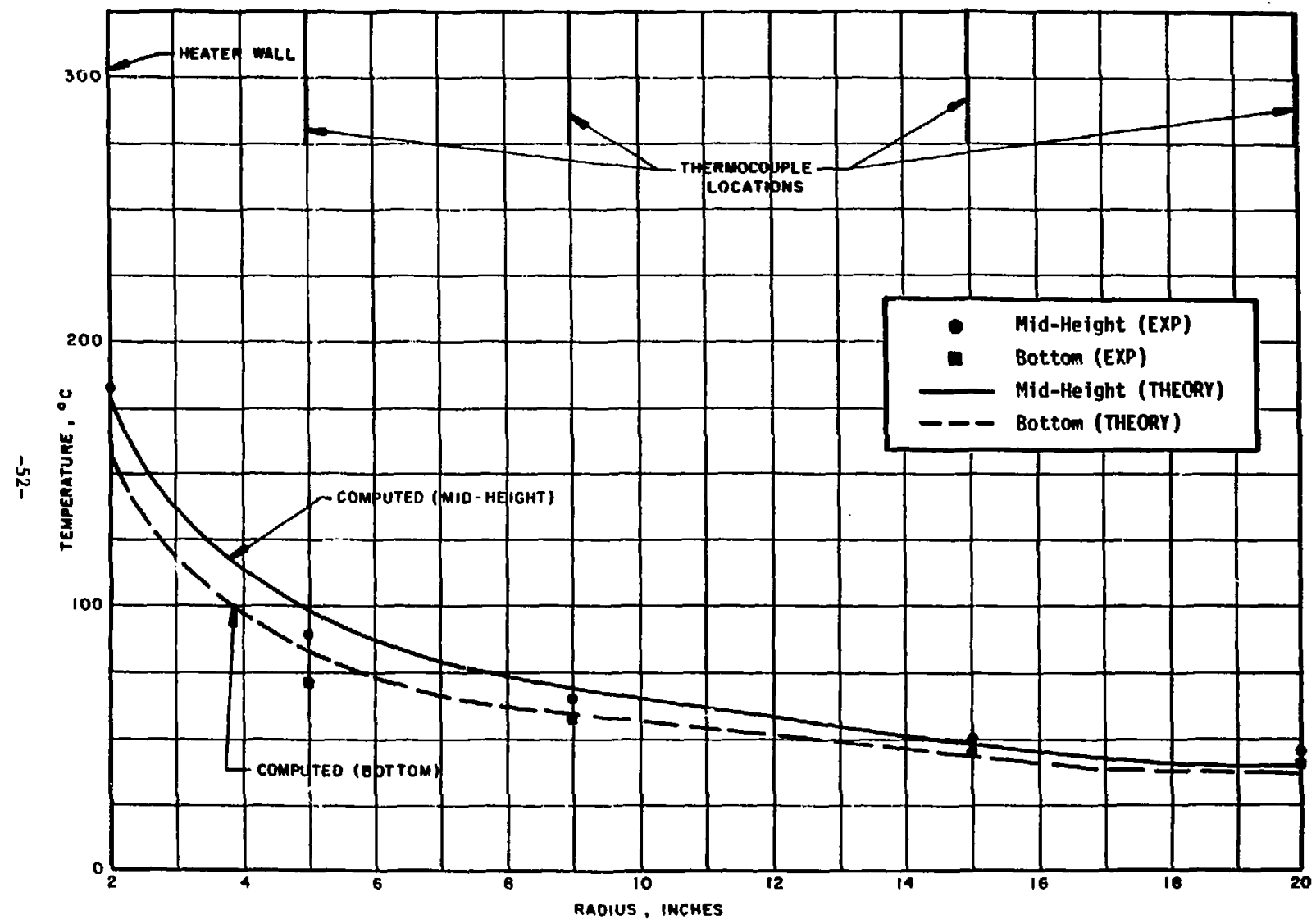

Fiqure 16. Steady State Temperature Profile Comparison: $0=750$ watts. 
TABLE X

COMPARISON OF MEASURED AND COMPUTED TFMPERATURES $Q=1,280 W$ (UNINSULATED)

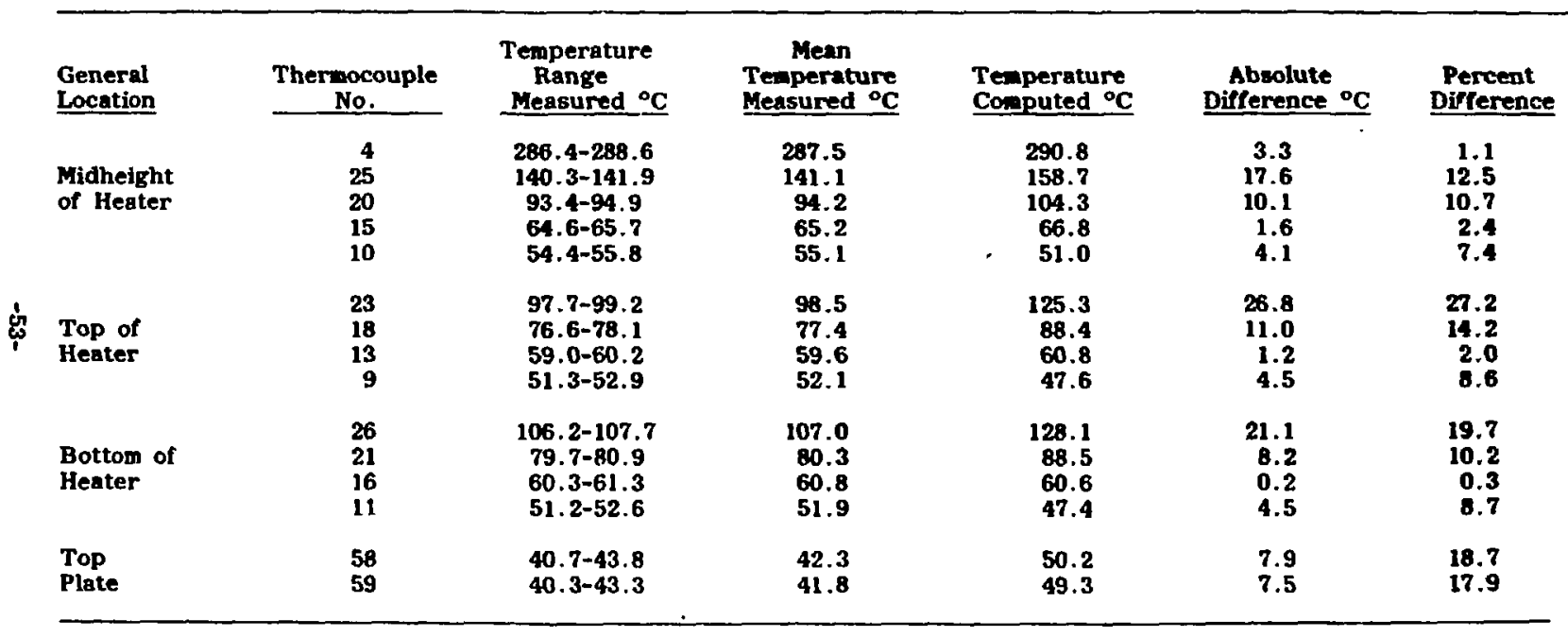




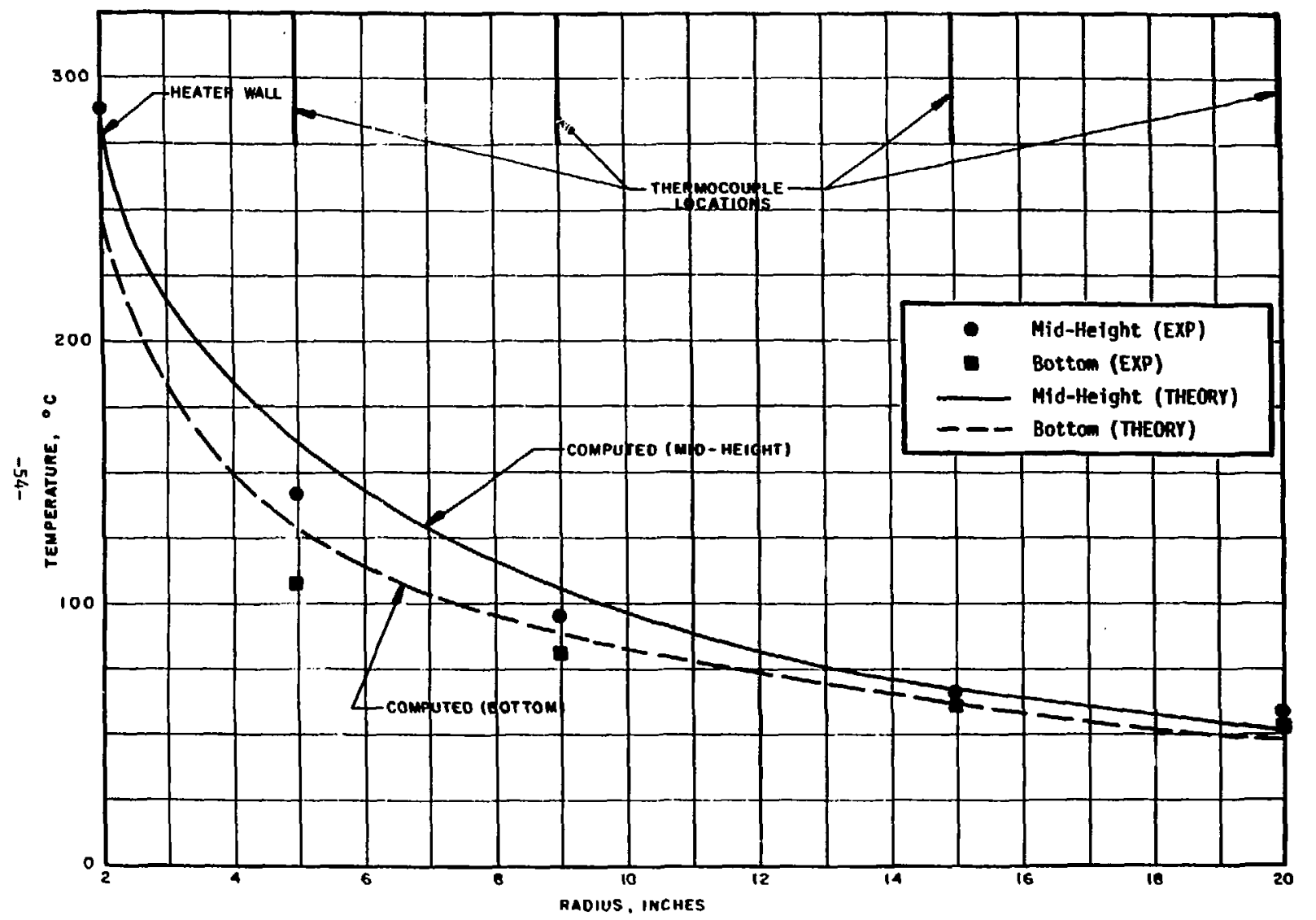

Fiqure 17. Steady State Temperature Profile Comparison: $\nabla=1280$ watts. 


\section{Transient Comparisons}

For transient experimental comparisons, the first 2 days of the Salt Block I experiment were selected. First, the input values are here calculated, followed by the results.

Over the first 2 days of the experiment, the outside surface temperature rose from approximately 18 to $24^{\circ} \mathrm{C}$. With a constant ambient temperature of $18^{\circ} \mathrm{C}$ assumed, the maximum convective heat transfer coefficient is (for assumed laminar now)

$$
h_{c}=2.218 \mathrm{w} / \mathrm{m}^{2}-{ }^{\circ} \mathrm{C}
$$

Radiation is neglected due to the low temperature.

Power input was varied the same as in the experiment. Resulting experimental-numerical comparisons are as shown in Figures 18 and 19 for day 1 and day 2, respectively, at four radial locations at midheight of the heater. The comparison of numerical and experimental curves is quite reasonable for these 2 days. The largest errors are seen to be near the heater during the first dey and at the first thermocouple (in the salt) during the second day. The first error is attributable to poor knowledge of the crushed salt conductivity. The second error is similar to that observed in the steady state comparisons. Recall that at the first radial salt thermocouple location, experimental values were consistently lower than theory.

\section{E. Discussion of Discrepancies}

While both steady state thermal profiles and transient temperature-time histories as recorded generally show very satisfactory agreement with predictions computed using the COYOTE finite element program, there nevertheless do exist some discrepancies that are worth brief commert. 


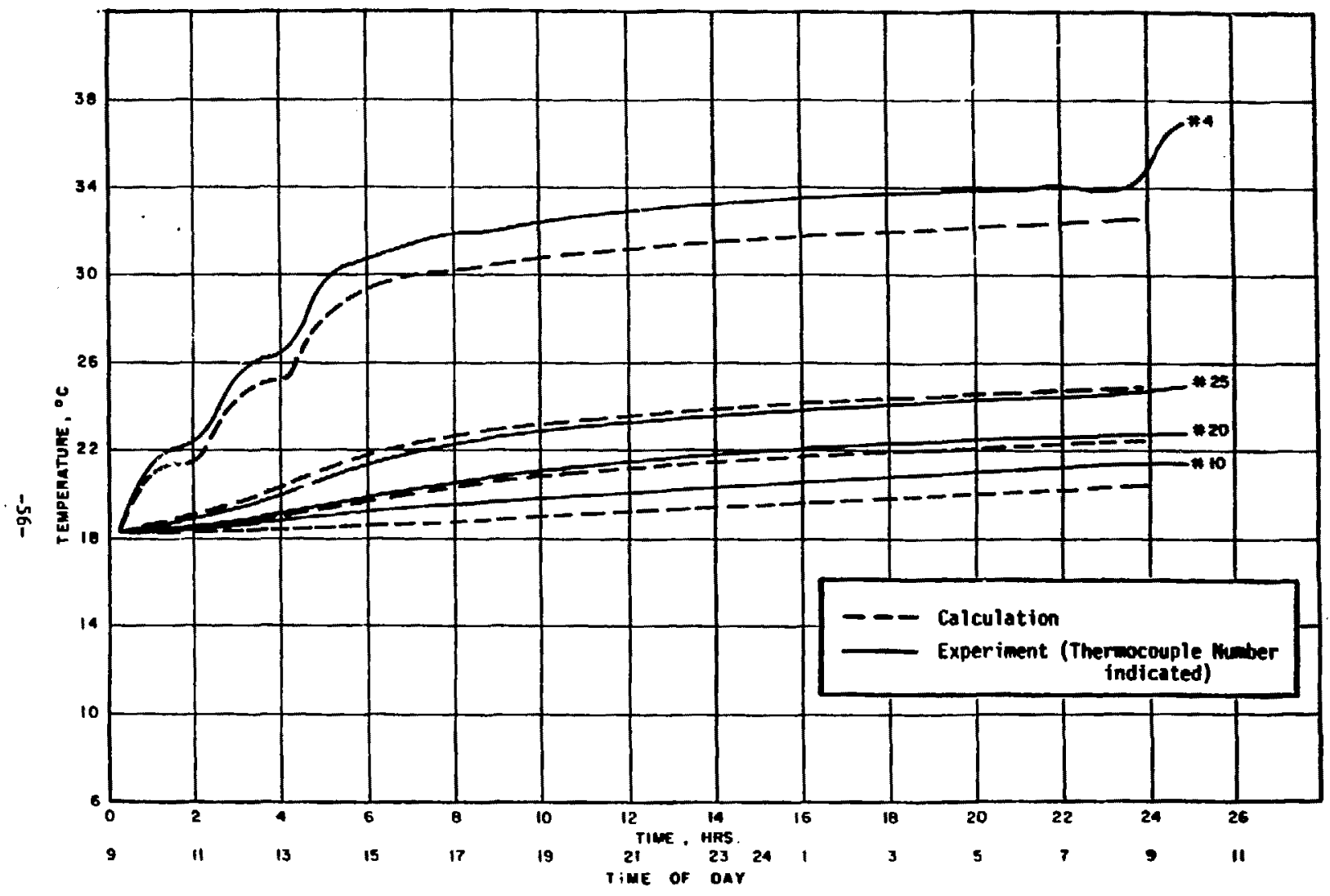

Figure 18. Experimental-Numerical Comparisons of Temperature as a Function of Time at Four Radially Spaced Thermocouple Locations: Day 1. 


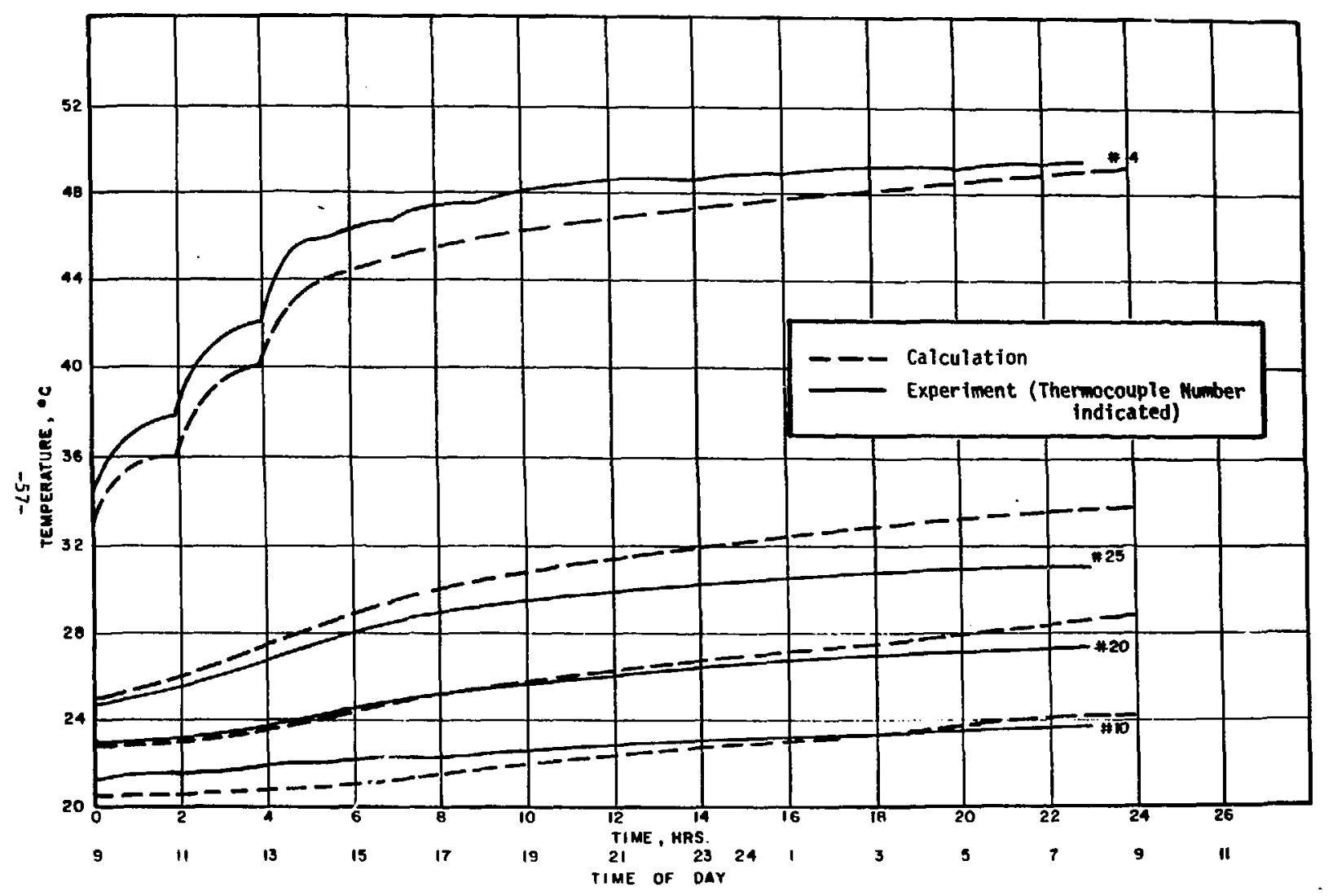

Finure 19. Experimental-Numerical Comparisons of Temperature as a Function of Time at Four Radially Spaced Thermocouple Locations: Day 2 . 
Thermocouples located on a 5-in. radius from the center of the salt block have output consistently below numerical predictions. Consider Figure 10 presented earlier. This figure shows locations of thermocouple holes as well as the locations of holes used for corrosion coupons. It can be seen that the corrosion coupon holes are significantly larger than the thermocouple holes; in addition, the inner coupon hole is located in the near proximity of the two inner thermocouple holes 4 and 5 (containing thermocouples 25,23 , and 26, among others). It is believed that the inclusion caused a perturbation in the temperature field, leading to the discrepancies observed between theory and experiment.

It should be mentioned that subsequent to performing the heat transfer finite element calculations, some more recent physical properties of bedded salt were obtained that are not reflected in the correlations presented earlier in this secton. The new rocksalt thermal conductivity data which were generated gave values substantially higher, as is shuwn in Figure 20. However, the earlier values (See Figure 3 and Table IV) were taken from the core of Salt Block I, while the later values were from another salt block in the same formation in the mine. Since the site specific Salt Block 1 values were utilized in the correlations presented herein, the best available salt properties (though not the latest reported values) were used and the basic conclusions of the Salt Block I are, of course, unchanged. The abr ve differences still should be kept in mind. 


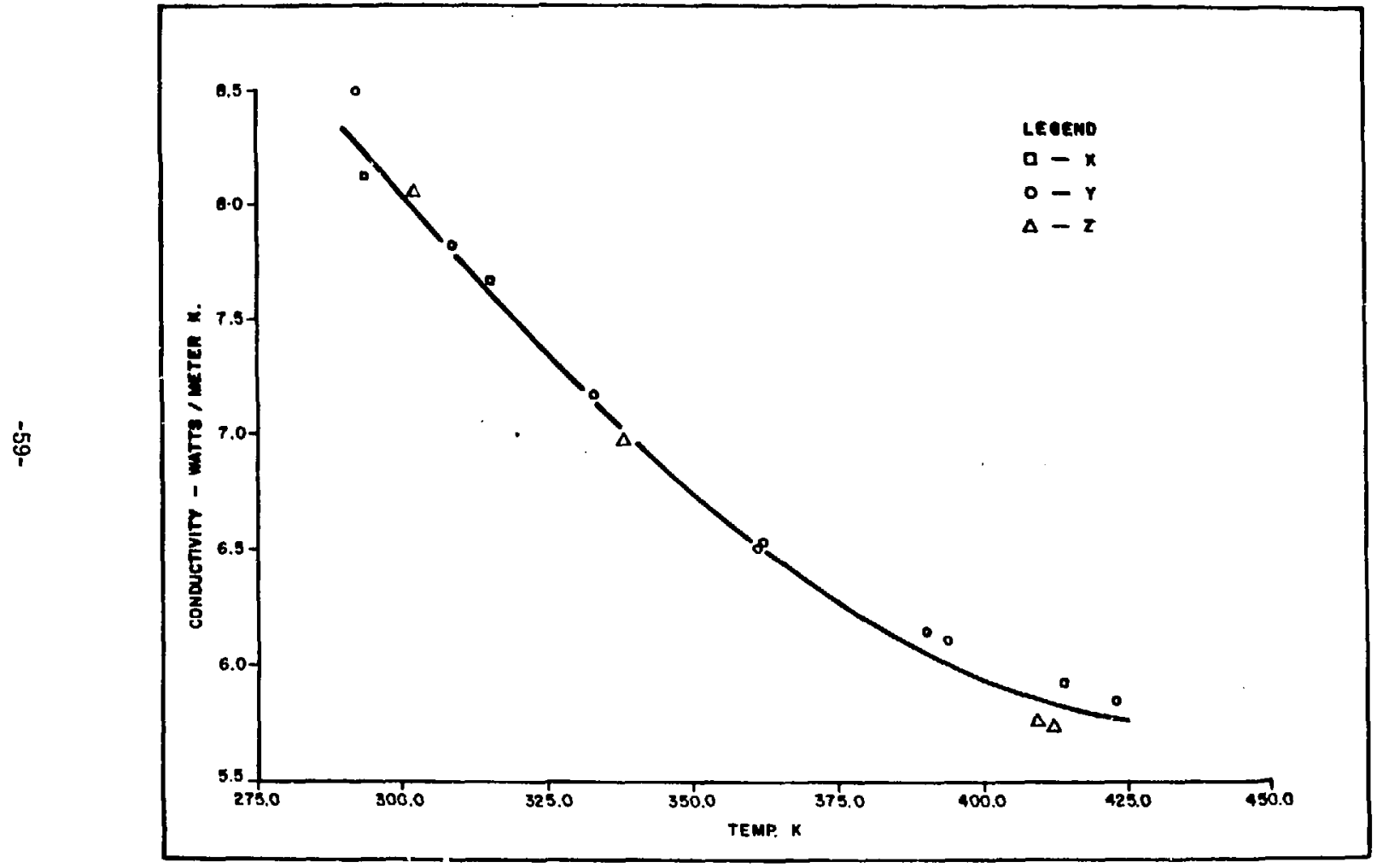

Figure 20. Thermal Conductivity of a One Meter Cube of Rocksalt From Mississippi Chemical Company of S. E. New Mexico Potash Mine - Latest Data 


\section{SECTION IX}

\section{SUMMARY OF RESULTS AND CONCLUSIONS}

The fundemental purpose of the Salt Block Test I, as stated earlier, was to provide data and information relating to the storage of radioactive wastes in salt. A number of specific objectives related to this underlying purpose have been accomplished.

1. A heat source has been developed, instrumented, and successfully demonstated for the purpose of simulating an emplacement of high-level waste in salt (see Section VI).

2. Based upon the axisymmetry of the recorded temperature field in Salt BJock I (see Section VI, Subsection D), as well as agreement with isotropic thermal calculations, evidence suggests that thermal conductivity of bedded salt may be isotropic.

3. Sauereisen cement and fine salt have been evaluted as backfilling materials (see Section VI, Subsection D). These materials were found to both yield identical therzocouple results.

4. The corrosion field in salt was investigated for a variety of different materials as part of Salt Block I (see Section VI, Subsection E). At least for this one experiment, results suggest that the corrosion problem in WIPP may not be very significant. However, additional experiments are recommended before any firm general conclusions are drawn.

5. Considerable experience has been gained in instrumenting bench scale samples of salt (see Section VI, Subsections A through $D$ ). It is believed that the instrumentation development undertaken in Salt Block I will prove valuable in later in-situ experiments. 
6. Preliminary data on brime migration have been obtained (see Section VI, Subsection F) where results surgest that water migration in salt formations is a minor phenomenon, at lesst at the temperature ranges experienced in Salt Block I. Again, additional experiments are required before stronger conclusions can be drawn.

It should be further mentioned that a numerical model of the salt block was developed for predictions of both tiansient and steady state temperature profiles. These predictions agreed quite well with the experimentally recorded response of the salt block to a thermal input. In addition, the following specific conclusions were reached:

1. Temperature dependent conductivity values measured on small salt samples (and reported herein) adequately characterized large salt block conductivity.

2. Crushed salt conductivity was estimated by repeated numerical parameter variations and comparisons with experimental results to be in the range 0.35 to $0.50 \mathrm{~W} / \mathrm{m} K$. This range in values is roughly an order of magnitude below bedded salt values.

3. Based upon spatial extrapolation of validated numerical temperature profile predictions, the pretest target of 200 to $250^{\circ} \mathrm{C}$ maximum salt temperature was achieved.

The need to closely match numerical and experimental data in this test forced the experimental setup and numerical model to be critically evaluated especially with regard to control of the thermal boundary conditions. As a result of this evaluation, a number of points can be made to aid in future experimental designs.

1. The layers of asbestos in the original experiment design were inadequate to prevent heat loss from the horizontal surfaces and piping leads, making the numerical modeling somewhat 
more difficult than anticipated. The experimental setup was oventuelly modirled to eliminate this problem.

2. In desigaing the experiment, only free convective losses were assumed to be important for the rejection of heat from the vertical surfaces of the block. During the running of the experiment, it became evident that at the higher power levels, radiation was also a significant heat transfer mechanism. The unexpectedly high power requirements for the heater were mostly a result of the radiation losses.

3. There was no control on the ambient temperature conditions surrounding the experiment. This made modeling difficult since the thermal sink temperature could only be approximated.

4. A weak point in the numerical model was the representation of the resistance heater. In hindsight, it would have been of value to know the heat flux distribution along the heater wall. The addition of several heat flux gages to the instrumentation will remedy this problem.

5. A second weak point in the numerical model was the lack of material data for crushed salt. If crushed salt is to be used extensively for the backfilling of canisters, reliable property data are mandatory. 


\section{SECTION $\mathbf{X}$}

\section{REFERENCES}

1. Internal Sandia Memo from A. A. Sattler, 1141 and P. L. Nelson, 1142, to Distribution, "Experiments in Support of Bench Scale Experiment: with Large Salt Blocks," December 7, 1976.

2. Internal Sandia Memo from R. V. Acton, 5842, to P. L. Nelson, 1142, "Thermal Conductivity of Rock Salt Core in Support of Bench Scale Experiments on Large Salt Blocks," December 21, 1976.

3. Internal Sandia Memo from A. R. Sattler, 1141, and P. L. Nelson, 1142 , to Distribution, "Operating Plan for Large Salt Block Heater Experiment 1 ," January 10, 1977.

4. Internal Sandia Memo from C. W. Cook, 1116, to L. R. Hill, 1141, "Observations of Instrumentation Performance During Salt Block 1 Test," May 17, 1977.

5. Internal Sandia Memo from D. K. Gartling, 1261, to Distribution, "Preliminary Report Salt Block Experiment - Thermal Analysis," May 17, 1977.

6. Internal Sandin Memo from J. T. Mcllmoyle, 1125, to Distribution, "Heated Salt Block Experiment," May 31, 1977.

7. Internal Sandia Memo from R. I. Ewing and M. P. Apodaca, 1112 , to A. R. Sattler, 4512, "Water Loss from the Interior of Salt Block I Due to Heating Cycle Tests," November 13, 1978.

8. Omega Temperature Measurement Handbook, p. A-4.

9. D. K. Gartling, COYOTE--A Finite Element Computer Program for Nonlinear Heat Conduction Problems, SAND77-1332, Sandia Laboratories, Albuquerque, New Mexico, June 1978.

10. E. L. Wachspress, Iterative Solution of Elliptic Systems and Applications to the Neutron Diffusion Equations of Reactor Physics, Prentice-Hall, Inc., 1966, Pp. 29-31.

11. W. H. McAdams, Heat Transmission, McGraw-Hill, New York, 1954, p. 173.

i2. J. P. Holman, Heat Transfer, Third Edition, McGraw-Hill, New Fork, 1972, p. 219.

13. B. Gebhart, Heat Transfer, McGraw Hill, New York, 1961, pp. 122-123. 
14. K. Kahn, Uber die Wirmeleitfuhirkeit von Salerrus (Thermal Conductivity of Crushed sait), Gesellschat fur Strahlenforschung mbH München, Institut für Tieflagerung Chusthal-Zellerfeld, West Germany, September 15, 1989 (Bandin Loboratories translation dated March 21, 1977).

15. R. D. Cheverton and $\boldsymbol{W}$. D. Turner, Thermal Analysis of the National Redionctive Waste Repository: Pro ress Throuch June 1971, Oak Ridge National Laboratory, ORNL-4726, December 1971, p. 38.

16. Internal Sandin Memo from D. D. Dees, 5831, "Salt Block I Volatile Content Measurements," July 18, 1978.

17. J. J. Hohlfelder, Measurement of Water Lost from Heated Geologic Salt, SAND79-0462, Sandia Laboratories, Albuquerque, New Mexico, July 1979. 


\section{APPENDIX I}

\section{WATER LOSS DATA FROM SALT BLOCK I (PART I)}

The first investigation was performed to provide further understanding of water loss during the Salt Block I experiment. The investigation, as described in Reference 7 , is as follows:

The residual water content of selected salt samples was investirated by measuring the weight loss of each sample upon heating to $250^{\circ} \mathrm{C}$. Samples were taken from two locations inside Salt Block I after its heating cycle tests were completed, and compared to semples of the same formation that had not been previously heated. The differences between these measurements were taken to be measure of the water driven out of the samples as a result of the heating cycle tests on Salt Block I. The samples from the center zone of the Block, near the heater, were heated to about $140^{\circ} \mathrm{C}$ during the heating cycle tests and showed a water loss of $0.05 \pm .02$ weight percent of sample as a result of those tests. The samples taken from the outer zone of the Block, near its wall, were limited to less than $60^{\circ} \mathrm{C}$ during the Block tests and showed essentially no water loss as a result, with an upper limit of 0.02 weight percent.

After the heating cycle tests were cc.npleted on Salt Block I, it was cut in half, and cores $4 \mathrm{in}$. in diameter by $10 \mathrm{in.}$ long were extracted at the locations marked "wall" and "center" in Figure 21. The cores were broken into small chunks and divided into samples weighing 20 to 40 grams each. Ten such samples were used from each location indicated by the corss-hatched region on the diagram. Unheated samples from the same formation and source as Salt Block 1 were measured as a baseline. Each sample was weighed to an accuracy better than one-tenth milligram, heated to $248^{\circ} \mathrm{C} \pm 3^{\circ} \mathrm{C}$ in a vented air oven for 100 hours, allowed to cool in a dessicator, and reweighed. The resulting percent weight loss averages and the observed standard deviation among the samples are shown below. 
Los Alamos Technical Associates, Inc.

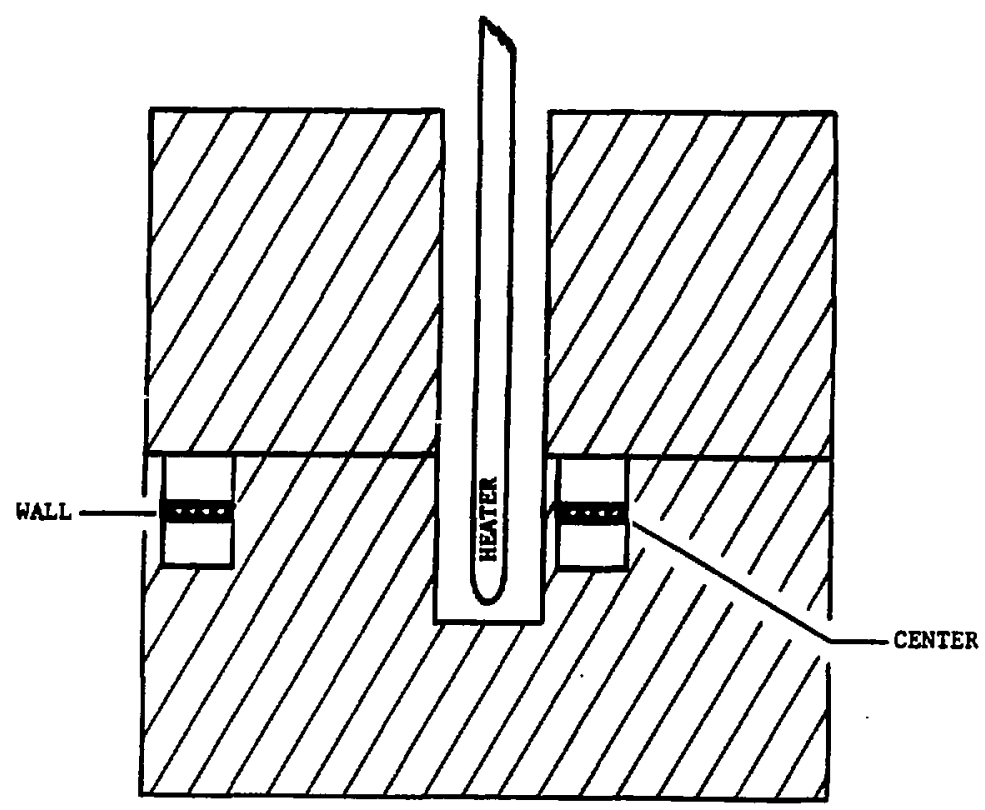

Figure 21. Section of Salt Block I Showing Locations of Sample Removal. 
Experimental uncertainities were much saller than the standard devintions. $250^{\circ} \mathrm{C}$ was the maximum sefe temperature to avoid decrepitation of the salt samples. The samples were weighed at 72 and 100 cumulative hours of heating, and no significant weight changes were observed after 72 bours.

\section{Sample}

Unheated

"Wall"

"Center"
\& Weight Loss

Upon Heating to $250^{\circ} \mathrm{C}$

$.12 \pm .03$

$.12 \pm .02$

$.07 \pm .01$

Results were analyzed under the following assumptions:

(1) the observed weight loss is due to water being driven out of the sample;

(2) these sampies all had the same initial water content (prior to heating); and

(3) the differences in the measurements are due to the prior thermal history of the samples, i.e., the heating cycle tests of Salt Block I.

Since the "unheated" and "wall" samples produced the same percent weight loss in our tests, it is concluded that the salt formation near the outer wall was essentially unchanged in water content by the heating cycle tests on Salt Block $I$. The "center" samples showed a lower percent weight loss in our tests than the other samples. It is concluded that the difference in these values, $0.05 \pm .03$ weight percent, is a measure of the water lost by the salt formation in the vicinity of the central heater due to the heater cycle tests on Salt Block 1 .

For comparison, earlier work is reported in Reference 17 using a similar technique on samples of previously unheated salt from the same 
formation. Figure 22 shows cumulative weicht loss percentage for temperatures from $70^{\circ} \mathrm{C}$ to $300^{\circ} \mathrm{C}$. The rapid increase in weight loss above $250^{\circ} \mathrm{C}$ and the increased standard deviation among the samples accompany the decrepitation phenomenon. The value of .10 \pm .02 weight percent at $250^{\circ} \mathrm{C}$ is in rough acreement with the present data. Also these comparison data indicate a value of about $.03 \pm .02$ weight percent for the difference fetween $60^{\circ} \mathrm{C}$ and $140^{\circ} \mathrm{C}$ samples, again in rough ugreement with the value of .05 \pm .02 ("wall" -. "center") reported above. The conclusion from this earlier data is that at a fixed temperature, only a certain fraction of the total water content can be removed from the formation even after heating for several days. The implication of these results is that "water migration" in salt formation is a minor and easily measured phenomenon. 


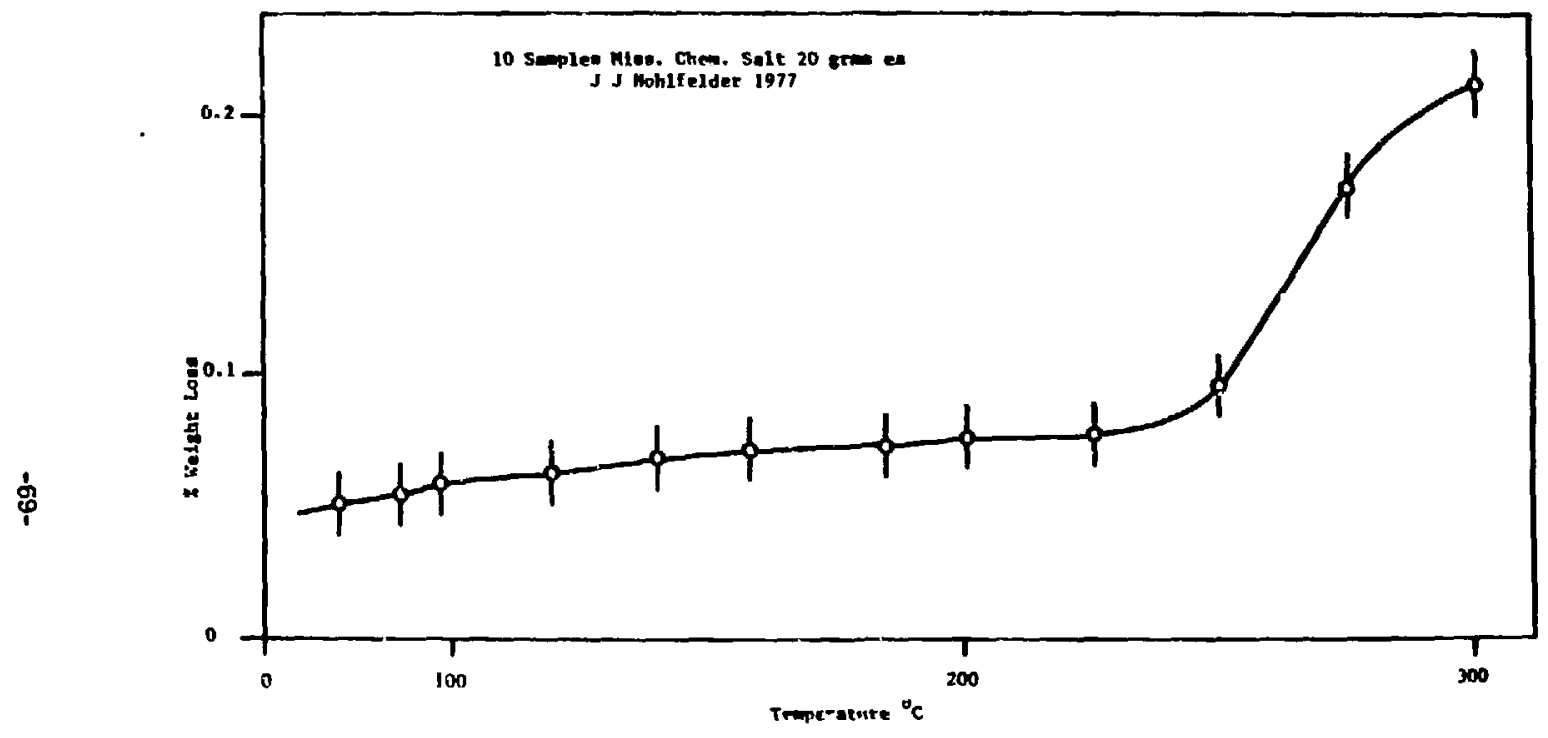

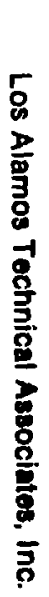

Figure 22. Percent Weight Loss as a Function of Temperature from Previously Unheated Salt Block I Samples. 


\section{APPENDIX II}

\section{WATER LOSS DATA FROM SALT BLOCK I (PART II)}

The second set of measurements ${ }^{16}$ on Salt BIock I directed toward detection of possible brine migration was obtained at higher temperatures as follows: tests were performed on three salt samples involving heating the samples in air at $500^{\circ} \mathrm{C}$ for 12 days. Each sample consited of 40 grams of ground salt (particle size less than $2.4 \mathrm{~mm}$ ).

The first sample (1001) was prepared from a specimen of Salt Block I before the Salt Block I heater experiment was performed. The second sample (1002) was prepared from salt from the outer part of the block after the Heater Experiment. Finally, the third sample (1003) was taken from the center section of the Block after the Heater Experiment.

A weight percent volatiles (percent waight loss) was determined for the salt using procedures similar to those described in Appendix I. Results for the three samples are as follow:

$\begin{array}{cc}\frac{\text { Sample }}{1001} & \text { Weight Percent Loss } \\ 1002 & 0.46 \% \\ 1003 & 0.47 \% \\ & 0.53 \%\end{array}$

Notes
From Salt Block I before heating
From outside of Salt Block I
after heating
From center of Salt Block I
after heating

